\title{
THE TRAGIC EXPERIENCE OF INSIGHT IN THE MEMORIAL LITERARY TEXTS OF RUSSIAN JOURNALISM, POETRY, ART AND ARCHITECTURE OF THE 1940S
}

Summary: The article, brought to the attention of readers, develops the outlined sections of the author's report "The Theme of Death and Immortality in the Fine Arts of the Modern and Contemporary Times" presented at the conference of the Research Institute of Theory and History of Fine Arts of the Russian Academy of Arts (November 21-22, 2019). The initiators of the conference explained their choice of one of the global and eternal themes of world art related to the very essence of the existence of humankind and each person by the fact that if ethnologists and culturologists have systematically studied certain aspects of thanatology, the existing extensive art material has yet to be brought together. Of the priority areas proposed by the conference program compilers, the author of this article chooses to say: "There is no death!": the theme of immortality, resurrection, eternal and repetitive life in art". The theme of memory, which occupied an important place in the art of the Great Patriotic War, is the subject of research of the published article. It is most fully expressed in such a field of creative and scientific thought of the war years as memorial architecture. Widely held contests for the projects of monuments became a noticeable phenomenon of the artistic life of those years, and the graphic works were included in the

The memorial theme permeates all the art of the war years. The changes taking place in people's minds may be seen by addressing the main human and cultural themes in literature and the art of wartime - Life, Death, Immortality. They are the fundamental categories in the coordinate system of a speculative philosophical model of the world structure (being), that is, "the presence of the world" (in a phenomenological sense), and the model of "the presence in the world", that is, a person's place in it, his existential experience. Turning to these main human and cultural themes in literature, art, and architecture of the wartime period, one can see what sig- valuable fund of Russian cultural heritage. Observing the birth of a new monument, the author of the article notes that memory and remembrance concepts underwent significant changes during the war years. The attitude to memory became an essential measurement of the very concept of memoriality, its worldview, semantic and symbolic content. Identifying the ways of interaction of the perceiving, experiencing, and interpreting consciousness, during which the mythologeme of "return" begins to be realized, a kind of regeneration of damaged cultural tissues takes place, is the purpose of this small study. The review of the archetypal concepts of "Life, Death, Immortality", these main subjects in the works of literature, fine art, and wartime architecture, allows us to see what significant qualitative changes occurred in the spiritual world of an individual and led to profound changes in the artistic and cultural process in general.

Keywords: the art of the period of the Great Patriotic War, design and construction of the first military monuments, creative and scientific thought of the war years reflected in the theme of memory, a return to universal values, spiritual ascent with a new experience adapted to profound (chthonic) ideas about the world, the nature and the place of man in it.

nificant qualitative changes were taking place in a person's spiritual world. At this tragic moment, the strength of the human spirit evoked deeply existential meanings, timeless, basically.

The awakening of historical memory became the moral support of a man. The memorial theme is reflected in journalism, poetry, and architecture in search of forms of perpetuation. The centuriesold tradition of art has accumulated a considerable supply of artistic means and has created a stable system of types of memorial structures. However, certain life situations and events made their adjustments every time, giving rise to new variants 


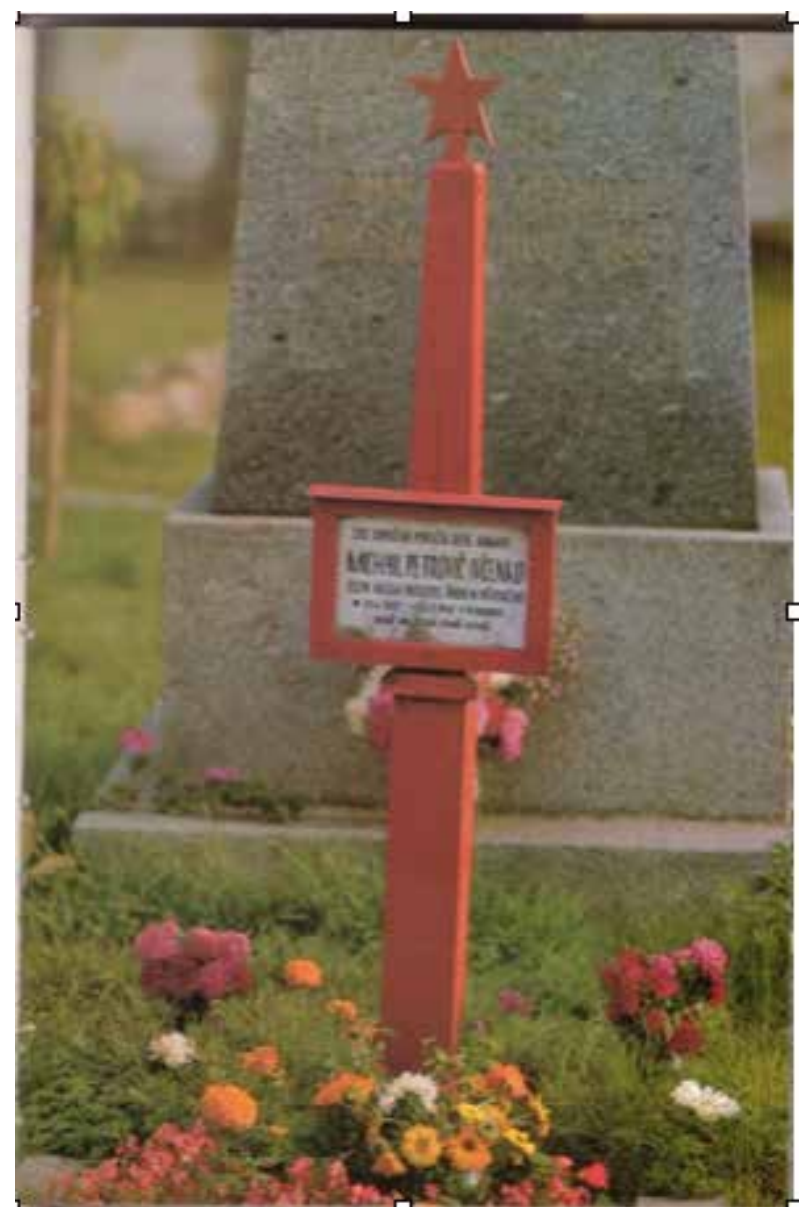

Temporary wooden memorial sign at the burial site. Preserved and placed next to a granite tombstone. Ceske - Budejovice. 1970s photo

of different types. As is known, after the 1917 revolution, the ideological and materialistic justification of the role of memory in socio-political life and the importance of mindfulness in this paradigm followed a simple scheme. Such concepts as Eternity, Glory, Immortality were associated exclusively with the hero's merits to the revolution and his absolute impersonality to eternity as a soldier of this revolution. The semantics and symbolism of a revolutionary memorial sign more or less distinctly expressed the prevailing ideas about memorialism. In contrast, the language of the memorial forms was poor, unambiguous, and mechanistic.

Everything changed in a military monument of the period of the Great Patriotic War, starting with a simple sign on a site of an individual burial. In the situation of World War II, which threatened with the complete extermination of the country's population, the consolidation of all forces was necessary. The declaration of this Patriotic war testified to the readiness of the prevailing ideology to compromise with other sectors of society and, first of all, with the peasantry, its more conservative layer, in which, nevertheless, the basis of the unity of the people,

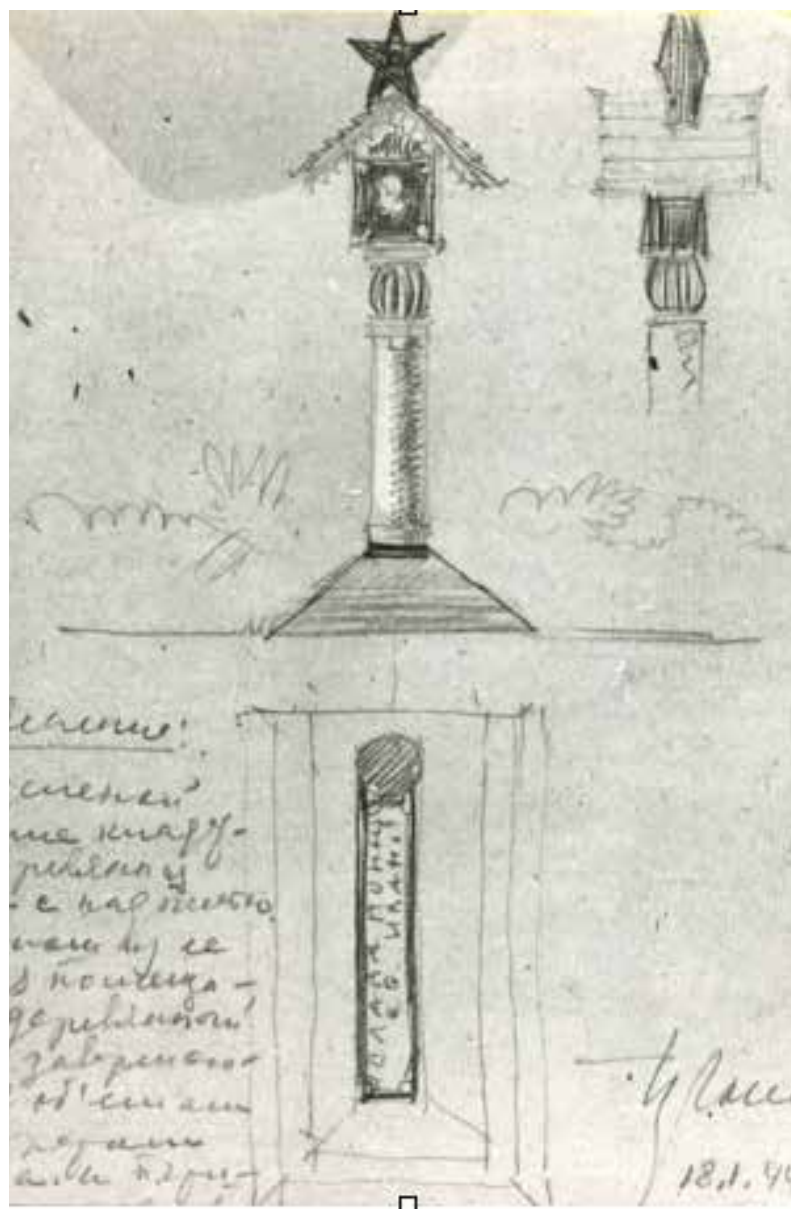

Golosov I. Temporary wooden memorial sign for individual burial. Sketch. 1944

this vital resource of the desired victory, was saved and preserved. The emphasis on society's class social stratification was softened by the compromise concept of "the people". In essence, the Christian motivation of an individual for his readiness for sacrifice was also important. Feeling himself a defender of the common, with which he is bound in being, from which he originated, that lasts in the offspring - his land, his people, man is ready to sacrifice his life to preserve this common. The consciousness of the responsibility for one's own choice raises one's experiences to an existential level.

A philosophical and artistic thought tries to recall, guess, catch the rejected features, forgotten in the appearance, behavior, speech, character of people, reanimating the concept of "people", trying to recreate a certain renewed integrity of the nation. Hence the convergence of "the high" and "the low", folklore, the professional, possessing the features of a primitive and simply avocational in art; hence the re-emphasis in the choice of sources of inspiration, semantic, symbolic, and figurative structures of works of art. Inspired by intellectual efforts and deep feelings, by a sense of complicity to the peo- 

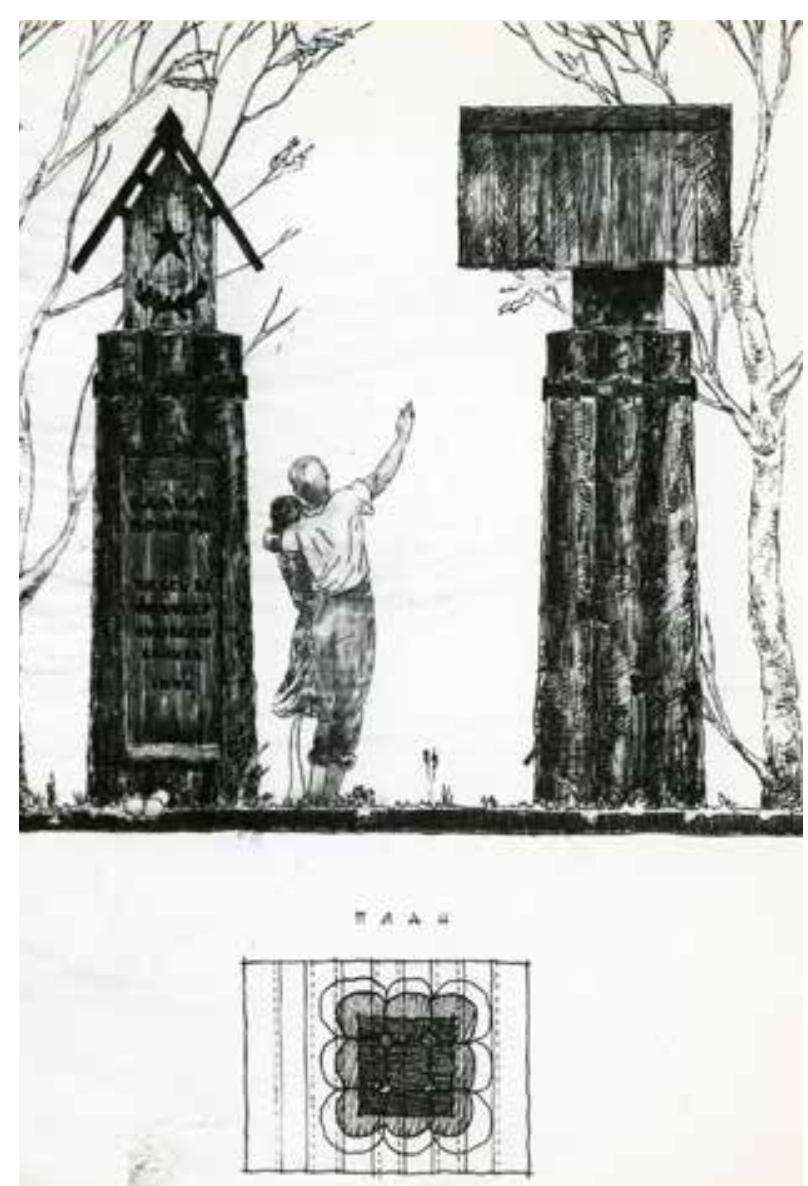

Znamenskaya E. Monument-spring at the site of a collective burial. Sketch. 1942. Kept in the architectural office of the USSR Ministry of Defense Forces, now in The Shchusev State Museum of Architecture

ple's destiny, answers to the main questions ripen in art: "in whose name" the life is given and "what is there on the other side of life".

Monumental art, the sphere of which includes memorial architecture, reflected the cultural processes of its time as a mirror. Various impulses of the polyphonic experience of the worldview, intense spiritual search, religious reflection, perceived by artistic thought, are focused on the work on the monument. "If we choose such definitions as a monument and a memorial from all the names of a single procedural whole," S.Vaneyan notes, "we can come face to face with very remarkable and almost essential dimensions of artistry and visuality". In the image of a monument and a memorial, a philosopher sees the expression of the intertwined reflexive impulses of "the perceiving, experiencing and interpreting consciousness, behind which, if desired, important ontological or existential horizons of human beingness and eventuality may be seen" ${ }^{1}$. And indeed, it is here where the answers to the fundamental, eter-

1. Vaneyan S. "A Work of Art - from a Monument to a Mnemotope" // A Work of Art as a Document of the Era. Collected works edited by T.Malinina. Part 1. Moscow: BuksMArt, 2014. P.33. nal questions of human existence are sought: about God, man, and the world, history, and eschatology, death, and immortality. Everything that happened in the people's world outlook, worldview was reflected in the art of the war years; it was essentially a return to universal values, profound, "chthonic" (earthen) ideas about the world, nature, and a person's place in it, and spiritual ascent with the new experience adapted to the new reality. The appeal to archetypes, to the very substance of Being, can be called ontological memory.

Actual "tasks of the day" and "eternal" problems are directly linked in the civic, moral, socio-philosophical reflections of creative individuals. "They were preparing to become prophets / My comrades," B.Slutsky later said.

A unanimous appeal to the roots of the national culture was the consequence. The mythologeme "return" began to be realized. It happens simultaneously at different levels of "interpretative consciousness": below - the people's elements, and above - the cultural memory. Understanding history, not as the long-gone past but as a link in the continuous process of being, the experience of many generations, which is characteristic of the people's worldview, nourished art images. In particular, architects' interest in "folklore" memorial forms testify to the new value guidelines. Real impressions of what was seen at the front and seen in everyday life formed this interest. An incredible number of individual burials marked with self-made commemorative signs were found on a vast territory at that time: wherever the fights took place. Made from improvised material, they became an integral part of the military landscape and military life. Former front-line soldiers often recollect precisely these monuments in their poems, which are dear to their authenticity and involvement in the burnt memory. A star of a monument appears in the imagination of poet S.Orlov, piercing the blue dusk of a dying day: "The tank battle ended at sunset / Motors rumbled / Panthers were burning out in the distance / Rolled / across the blue sky / Above the black earth / and fell / on a pine post / a star from plywood / [K.M.] (After the Battle, 1946). In the poem already quoted, In Memory of Poet Mikhail Kulchitsky (1952), Slutsky also has this image: "And lieutenants' marble - Is a plywood monument - The crowning of those talents, The denouement of those legends".

At the beginning of the war, descriptions of frontline commemorative signs can be found in 


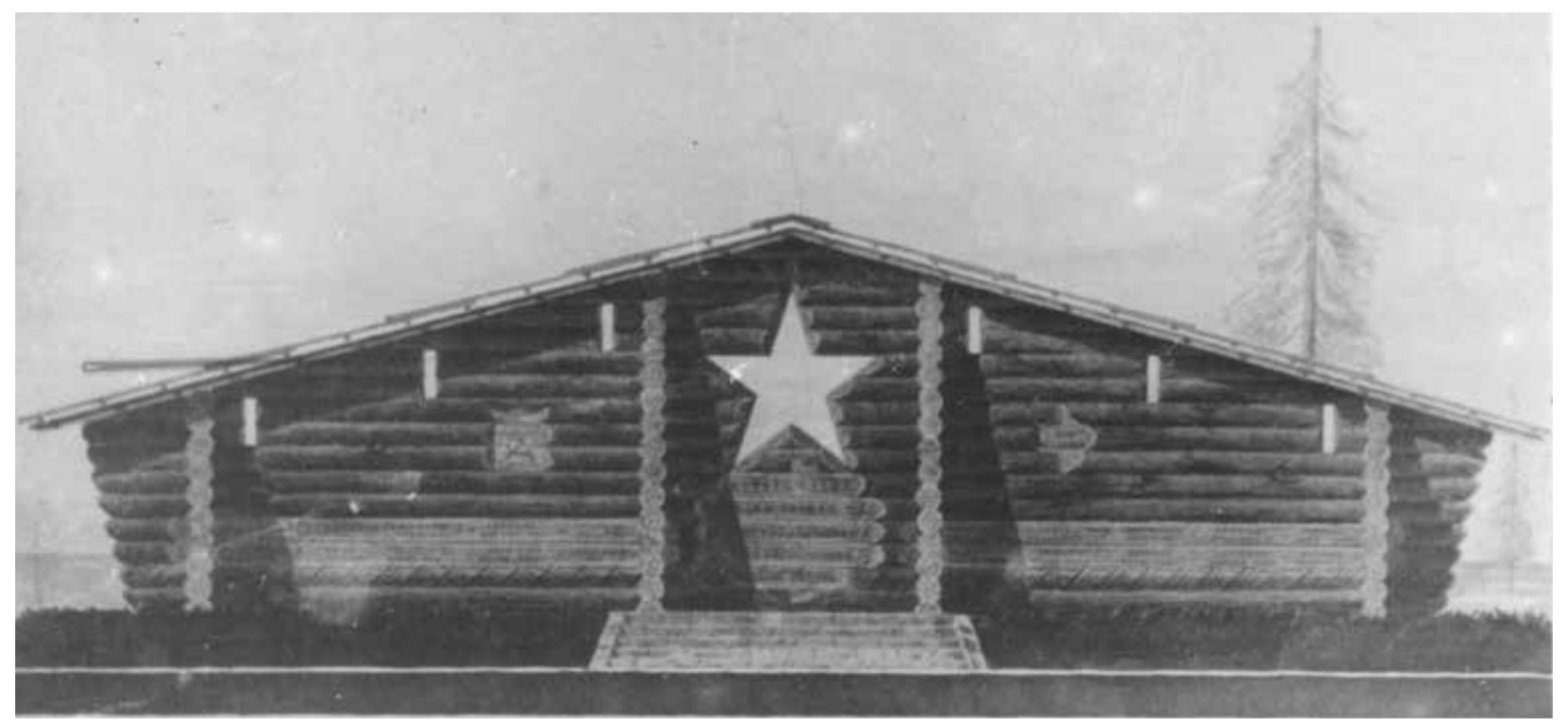

Dzisko M. Wooden stele at the site of a collective burial. Sketch. 1944. Photo of the architect's family

military commanders' essays: "An ancient wooded lake region. Hills, rivers, hollows, hills again. One of the hills is called "a bald height". There is nothing on the top; from below, it is densely covered with shrubs - indeed, a bald head. A red hexagonal obelisk stands behind a white birch fence, among the four recently planted young fir trees on the top of a scattered hill... On the right, there is a half-broken machine gun, wheels resting on spring red earth... We get down from the hill, we pass the forest; but still, far beyond the forest in the warm haze of a spring day, a high red hexagon is visible on a bald hill - a symbol of the Red Army valor, eternal Russian glory, immortal military honor" ${ }^{\prime \prime}$. The journalist easily reads the semantic components of a small tombstone: revolutionary color symbols, military emblems, and a classic memorial pyramid shape symbolizing the heroic beginning. Miraculously preserved in some places in cities, on the outskirts of villages, near roads, such monuments acquired a special artistic meaning. Despite all the imperfections, they are always recognizable documents of the era, affecting their authenticity more strongly than other tremendous memorials created after decades. The memorial sign and its environment are perceived as a single image - the image of time. It is no coincidence that, in the album entitled "VAM PODEKOVANI A LASKU VAM"2 ("Thank you and love you") published in South Bohemia, we see that next to the later, permanent tombstones of our soldiers, the original temporary commemorative signs were saved in the 1970s...

The idea of creating temporary wooden commemorative signs on the burial sites arises under the influence of such improvised tombstones in the form of a birch column with a star cut out on it, a pine peg with plywood sheet, a wooden obelisk made from boards and painted. The army team voices it, and architects undertake to implement it. Naturally, a wooden Russian tombstone became a source of inspiration for a sculptural interpretation of small memorial forms: in places of individual burials and on small mass graves. It is this motive that becomes important in the poetic understanding (reinterpretation) of the meanings that military commander, writer, and politician K.Simonov puts in the concept of the Motherland in the poems The Motherland (1941), Do You Remember, Alyosha, the Roads of Smolensk?! (1941), in the essay "On the Old Smolensk Road" (1943) 3 . The author turns sincere personal lyrics into civic lyrics. The feeling of the Motherland is nourished by nature close to the heart ("a patch of land close to three birches", "that handful of land in which one can see the signs of the whole earth in it"). Cautiously, as if thinking, the poet turns to A. Surkov with the words: "You probably know, it is the Motherland after all".

3. Simonov K. "On the Old Smolensk Road" // Krasnaya Zvezda, No. 63, March 17, 1943.

1. Gabrilovich E. "The Mass Grave" // Red Star. 1942. May 16.

2. Smid Stanislav. Vam Podekovani a Lasku Vam. Bratislava. 1975. 

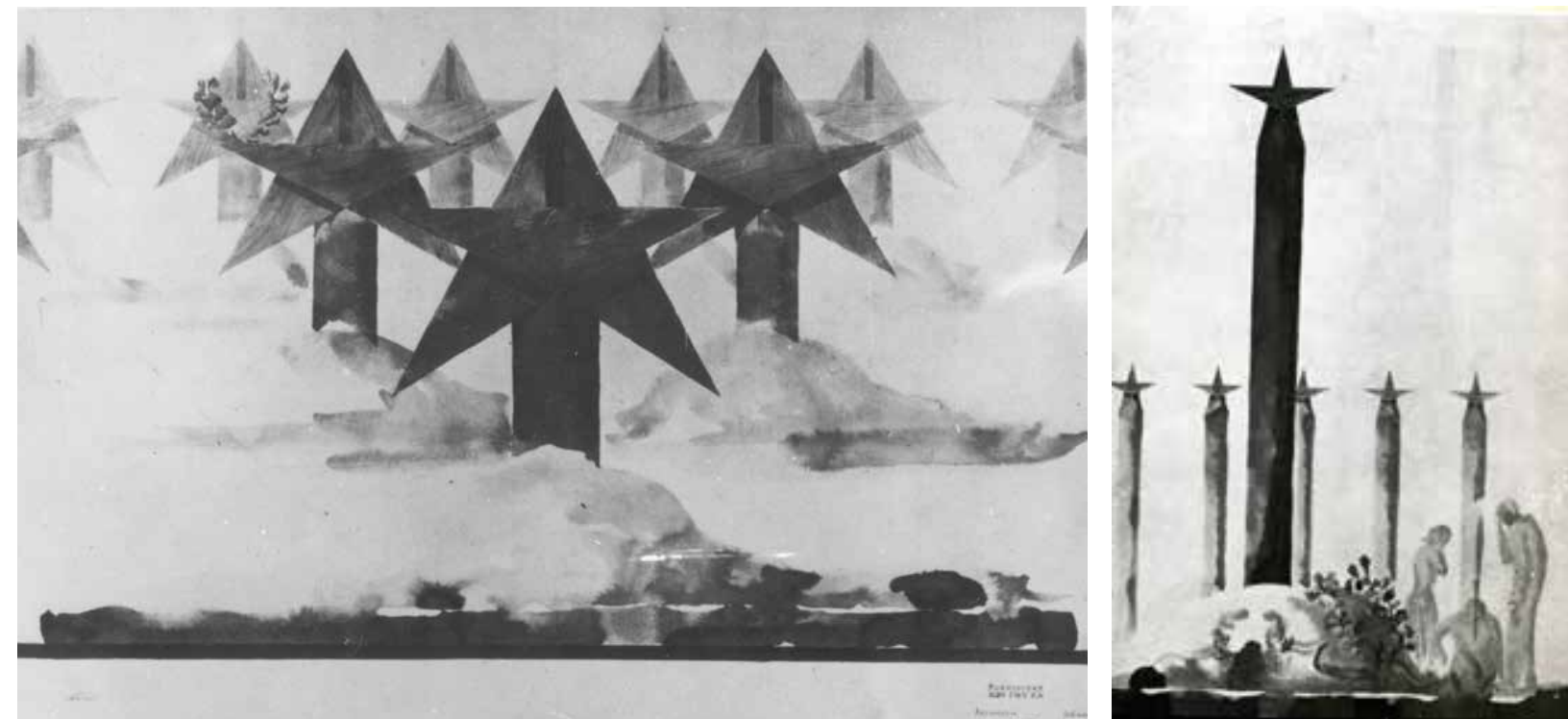

Gaigarov N. Temporary wooden tombstone. Sketches. 1944. Album of sketches of wooden tombstones made by Gaigarov at the Institute "Voenproekt" in 1944. Collection of The Shchusev State Museum of Architecture (one of the sketches).

Further, the author admits that he sees the familiar landscape of the countryside of central Russia with entirely different eyes and especially values these impressions; those small villages in the Smolensk region with old crosses of graveyards darkened by the weather are the most valuable asset for which a person can give his life: "Do you feel what is our land like, how impossible it is to give it away, how impossible it is to tear out one's heart and want to still live after that". Surprisingly, the ideas that had recently seemed incompatible and even hostile are combined with such ease, thereby revealing an unnatural state of things in the minds of the bearer of the prevailing ideology. Thus, the idea of consolidation manifests itself in the poetic form, in the face of general danger. Another ideological component of this unity, which is far from accepted by all, is shown here, in the thought of forgiveness and reconciliation, which sounds in the lines: "It is as if in each Russian outskirts, / Protecting the living with the cross of hands, / Our greatgrandfathers, coming together all over the world, are praying / For their grandchildren who do not believe in God".

The active development of small memorial forms in the Union of Architects, in the Military Project, and the Academy of Architecture workshops prompted famous historian of Russian architecture P.Maksimov to turn to Russian wooden tombstone at the same time. In the article "Memorial Architecture of Russia" (1943-1945), the researcher described different types of wooden headstones and showed the dependence of their shape, silhouette, height, and decor on the natural environment ${ }^{1}$. A multi-colored wooden column with a bead ending in a cubicshaped volume with a portrait (or a commemorative inscription); there is a gable covering above it, similar to that of old wooden tombstones, completed by a star. This is how a temporary memorial sign looks like in one of Ilya Golosov's sketches, which resembles carved pillars painted in different colors at the forest cemeteries in Kemi, namely those described by Maximov.

Architect M.Olenev managed to meet two difficulty compatible requirements for a typical gravestone - on the one hand, to create stable signs of "type", and on the other, to maximize the possibilities of concretizing the contents of a typical gravestone. Olenev developed a whole system of symbolic forms, stylizing the pictorial attributes of military glory, emblems of the military branches, military decorations, distinctions, types of weapons, army accessories. He did this as a true artist, summarizing and revealing primarily the plastic qualities of the form. For the content of a tombstone itself, this concretization was an opportunity to get as close to an individual as possible, to give him the complete information. The unity of the constructive and decorative principles, the preservation of the main elements of the traditional tombstone, the principles of its compo-

1. Maksimov P.N. "Memorial Architecture of Russia". Pp.371-406. A manuscript of the collective monograph "Memorial Architecture of 1943-1946" // Memory and Time. From the art archive of the Great Patriotic War of 1941-1945. Responsible editor and compiler T.Malinina. Moscow: Galart, 2011. 

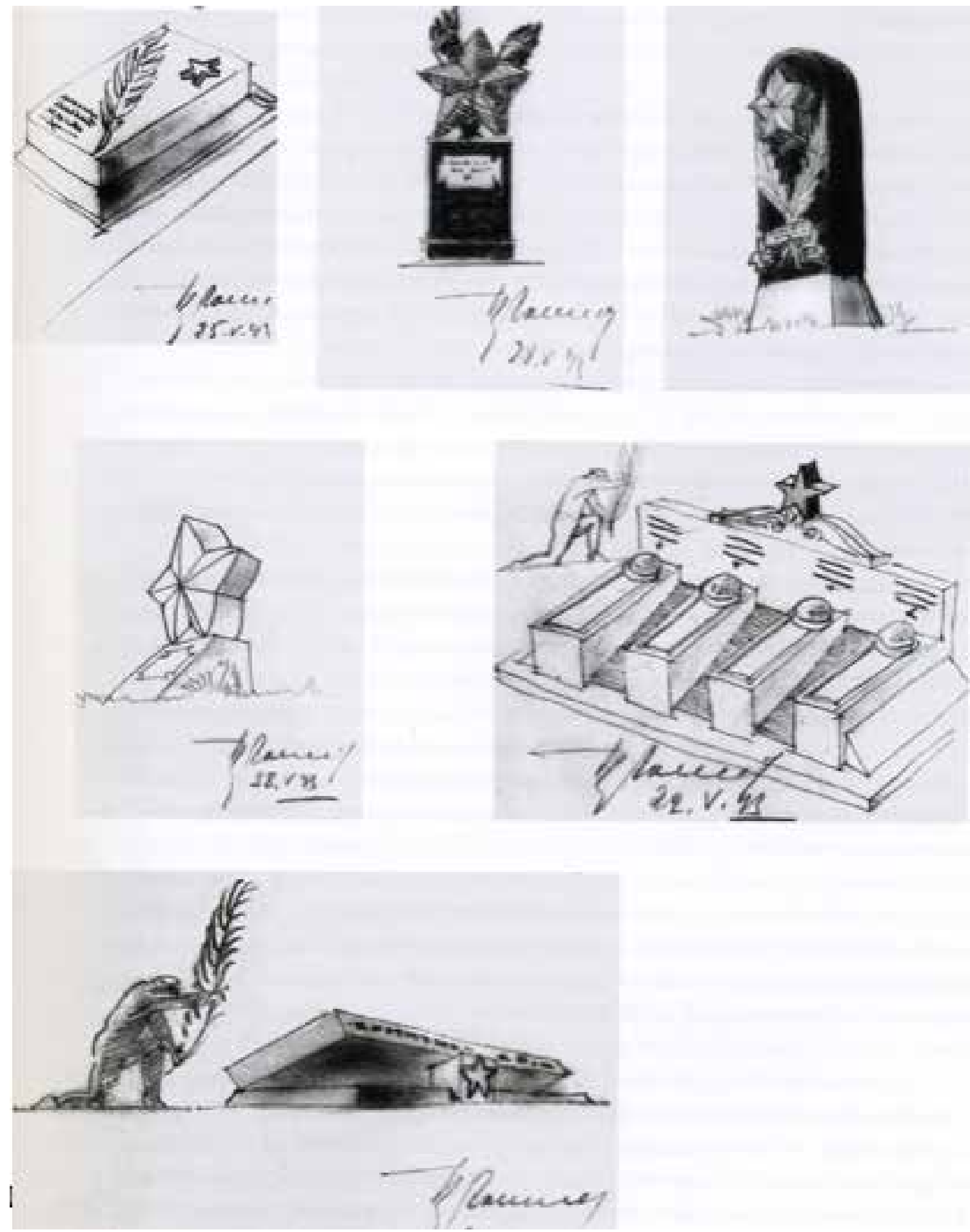

Golosov I. Drawings of gravestones 1944. Table 1 and Table 2. RSALI, f.1979, op.1, d.91

sition, the simplicity and expressiveness of details on the nature and interpretation of those close to folk wooden carvings, and the widespread use of polychrome are the main advantages of the monuments of Olenev's 1943 album. Olenev is a master of the lyrical image. A naive immediacy, a pure ideal initial feeling that captivates us in works of folk art lives in his monuments.

Architects tried to adjust the found designs by comparing them with samples. Here is what the rec- tor of Moscow Architectural Institute, Andrey Chaldymov (the Military Project), told about his own experience, speaking at a meeting of the Union of Artists and Architects on memorial architecture issues in June 1946: "... There is nothing to fear from national forms. I emphasize the importance of the first attempts to create a tombstone of a national character. An ordinary pillar symbolizes one person's burial, then - a closure, and then an icon or a cross. This form is caused not only by considerations of aes- 
thetics but also by tectonics. Therefore, when the modern form, the shape of a star, had to be considered in 1943, it took a lot of attention to how to "arrange" this element, how to create a general composition of the monument, how to place a star without embellishing anything, only to give such a pure form. I made a comparison table myself. If you make a pile of these stars, you get a "hedgehog." Imagine a sea of spiky stars. It will not be aesthetically pleasing, and such a form will not get along with the cross. The star had to be put on something. The first crossbar from simple constructive "shells" appears, then an inclined flat one that gives an image of peace..." ${ }^{1}$.

In the sketches for group burials, architects extensively used ancient Russian wooden architecture elements, enriching the forms with cultural meanings and art associations.

In the sketches of temporary memorials for fraternal burials, architects also extensively used old Russian wooden architecture elements. Round wooden "columns" often bore a direct resemblance to architectural decoration elements of the $17^{\text {th }}$ century. In more complex compositions, the motifs of a hip-roofed cov-
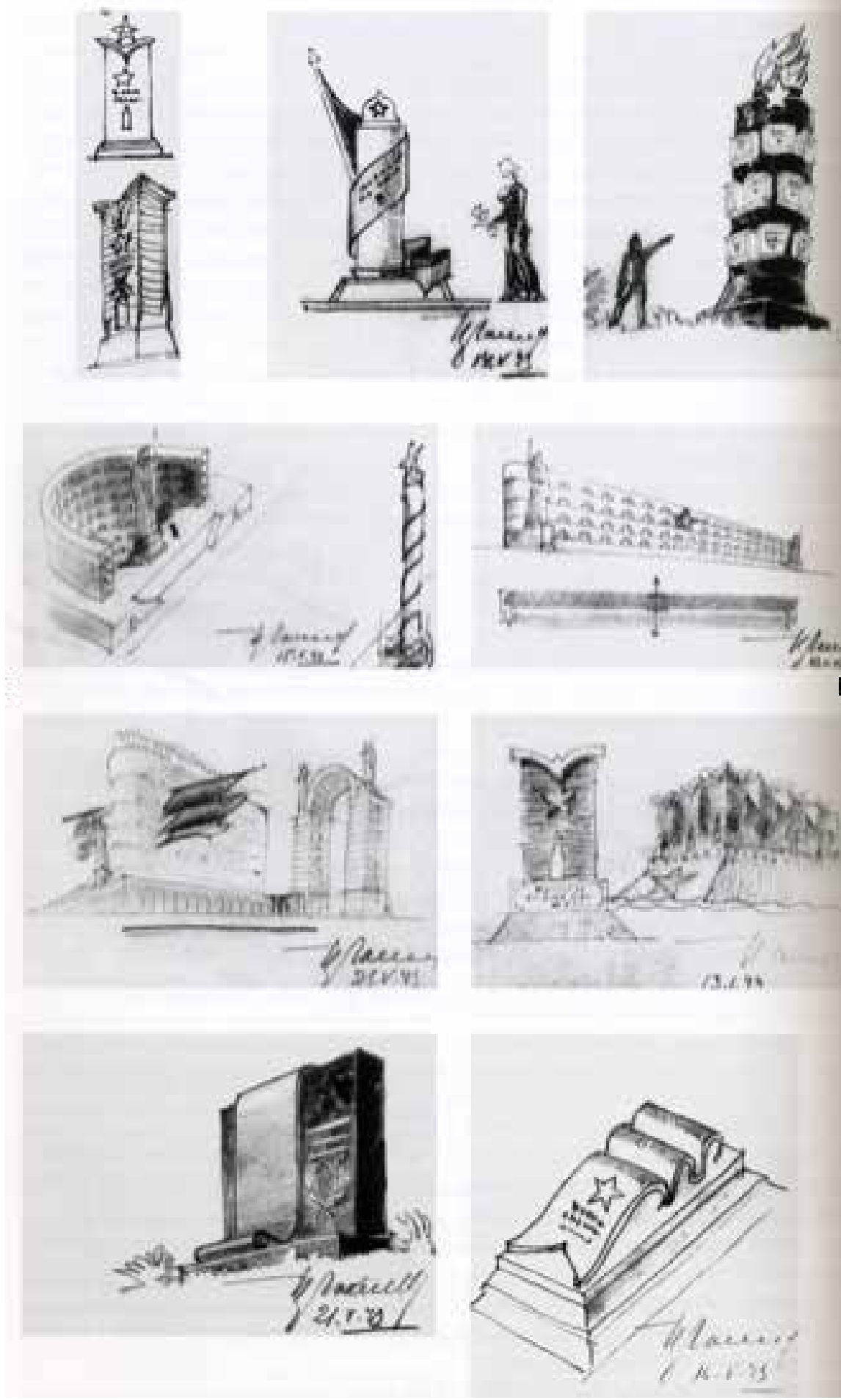

Golosov I. Drawings of gravestones 1944. Table 1 and Table 2. RSALI, f.1979, op.1, d.91 ering or "inner porch" were used. Following the long tradition of erecting small chapels near springs, architects designed monuments-springs (E.Znamenskaya). Some interpreted a tree as a memorial stela (M.Dzisko and N.Gaygarov. The Military Project). Narrow vertical holes-embrasures, cut through a log wall of a wooden house, were striking accents of Dzisko's memorial stela. In

1. From the transcript of the meeting of the USSR Union of Architects and Union of Artists on the issues of memorial architecture. June 3-5, 1946. RGALI, fond 674, inv.2, f.185, pp.67-68.

Gaygarov's project, a memorial stela, made of vertically standing charred logs, reminded of thousands of villages burned to the ground. These were unique works of architectural graphics shown at the exhibition "Heroic Front and Rear" (1943); today, they are stored in museum collections.

The military commander of the "Red Star", writer Andrei Platonov, has a pervasive death motif. However, the most fantastic thing is that the writer's stories about the war, about the murders and deaths, be- 
came stories not just about life but about immortal and eternal life. "Let's go, guys, there is no death!" this call to battle is in the story There is No Death! (1943). It is not a figure of speech, but it is what is rooted in mind, latently living and revealing itself at the moments of the highest spiritual uplift, such a force of high sacrificial impulse which can defeat death and is embodied in the Christian "trampling down death by death".

"A national intellectual, a working philosopher", as Russian philological researchers call Platonov, not only dared to raise the damned questions of human life in an extreme situation again but also gave answers - decisive and consistent but also expressed passionately and poetically exciting. ${ }^{1} \mathrm{He}$ broadcasted them through (philosophizing Platon Karataevs) the spiritual heroes of his military stories. During the war years, the author's ideas, close to the noospheric vision, were expressed in the world of his feeling and reflecting characters, their remarkable "persistence in being". Thus, the ritual of commemoration appears routine but unusual in Platonov's newspaper essay "Oath". The author leisurely narrates the soldiers' visit of the fallen comrades' grave as an event of everyday front-line life (the harsh everyday life). The atmosphere in which this silent farewell before a new battle takes place, the hardly pronounced unusual words of the company man with the surname of the hero of the novel Chevengur as if emerging from the depths of memory - all this is entirely unlike the loud rhetoric of "nationally bleached" revolutionary rituals that suddenly became inappropriate. "Old" words, speech forms, and figures of speech fill the commander's address with new meanings, allusions, and connotations, colorize it with new colors. A peasant basis of the people is felt in Chepurny's words: "our people have eternally laid down here, in the land", "to lead death from our people", the "pecuniary, life-preserving and lifesaving". The commander's words "they died for our Motherland" express the awakening of national selfconsciousness, explained by the severity of the historical moment when the personal and the public unite to fight a common enemy. The very space of meanings invested in the concept of the Motherland turns it into a territory of great compromise (national self-consciousness, religious consciousness, revolutionary consciousness).

1. Semenova S. Metaphysics of Russian Literature.V.2. Moscow.
The words "saints" and "a soul", the fundamental concepts of the Russian language picture of the world, need special commentary. In Orthodoxy, the concept of holiness appeared in the $11^{\text {th }}$ century. In modern times, when cultural paradigms are changing, primary meanings are supplanted by the dominance of secular or atheistic ideology. At the same time, words remain, and their meaning is interpreted in an expansive (figurative) sense. In this text, though, born of naive-linguistic understanding, the meaning of the word definitely shifts, acquiring a sacred shade.

In Platonov's essay "A Worker of War" (March 1943), the concept of "soul" is in the focus of the attention of the author and his hero. Ivan Tolokno was looking at the approaching tank, "and self-pity touched his heart for the first time". He had been working all his life; he had been tired, he had endured... And now they were shooting at him; they wanted to kill him, "so that Ivan's memory would disappear into eternal oblivion as if a person had not lived in the world. "You're lying! You won't take it!", thought Tolokno at the moment of death. Death for me, but the Soul will remain. Should stay. Probably, the Motherland is the soul". The soul is a reservoir of hidden thoughts and feelings of man. In the vocabulary of the prevailing ideology, this concept simply does not exist. So in the content of the word Motherland, in such vastness including a whole world of memories, experiences, and thoughts of a person, his hopes, the proportion of the ideological component is pushed back and narrowed.

Phraseologisms from the commander's speech "they survived the warrior's highest fate and fulfilled their duty without sparing blood and life itself" and "became holy people in the eternal memory of our Fatherland" go back to military rhetoric, to the heroism of the Patriotic War of 1812. In the already mentioned article, Maximov pays attention to the theme of military valor and glory in the architecture of Russian classicism, following the general tendency to appeal to Russian tradition.

The general picture of the spiritual climate of the era is complemented by an analysis of the historical experience of the art of recalling and interpreting cultural tradition, its correlation with modernity, demonstrated by Russian scientists: architectural historians, art historians, and archaeologists who took part in the work on a collective work devoted to the memorial theme in architecture. The name of the collective monograph "Memorial Architec- 


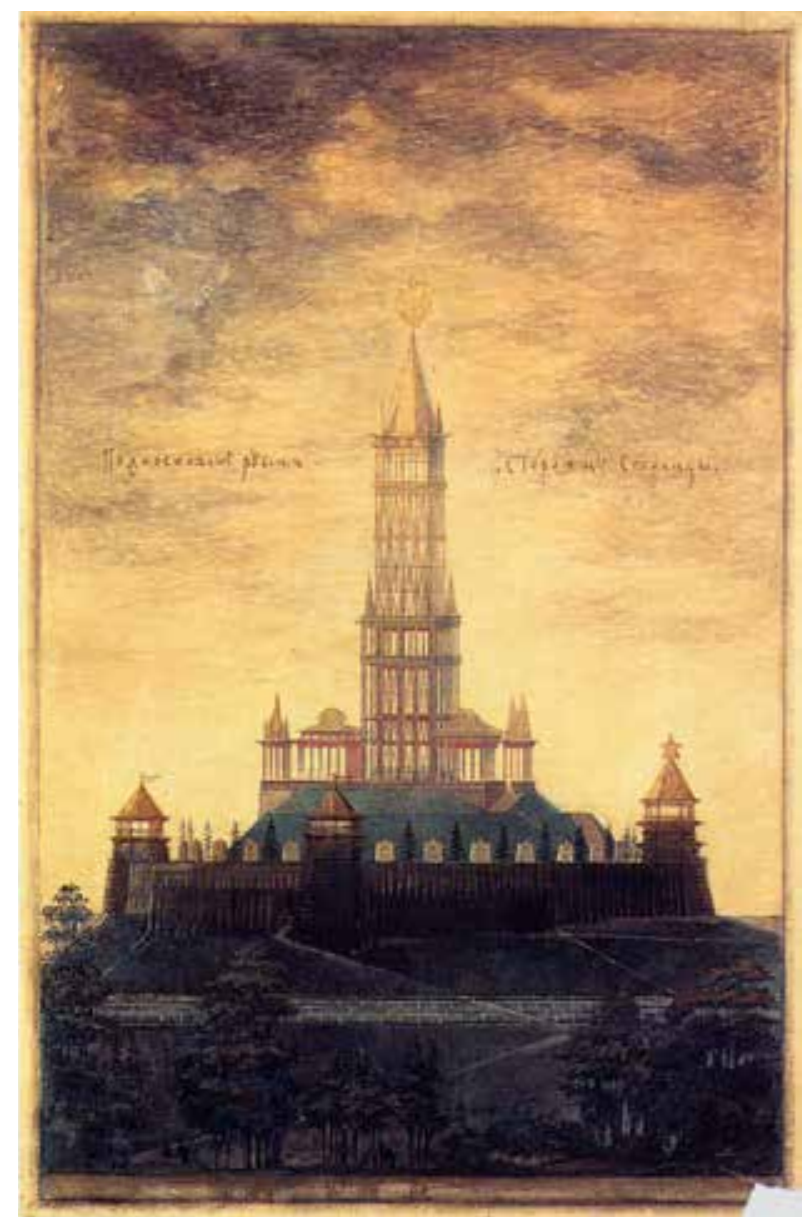

Unknown author. Competition project for a military necropolis. The motto is "Moscow Region Borders - the Guardians of the Capital". 1942. Collection of The Shchusev State Museum of Architecture

ture" (1943-1946) was not quite familiar to the ear. A.Gabrichevsky, a compiler, editor, explains in the introductory article: "Ruskin wrote about architecture in his time: 'We can live without it and pass away without it, but we cannot remember without it', and he continues the thought arguing that architecture is always to a certain extent memorial as a monument to human labor and human art above all. This quality finds expression in the system of artistic features, which we call monumentality" ${ }^{1}$. The expansion of the boundaries of research, going beyond the boundaries of memorial architectural typology into a wide space of cultural memory, is the main feature of Gabrichevsky's concept. Another author of this collective work, V. Blavatsky, reveals the values of ancient culture in poetic images, deciphering plastic analogs, or finding analogs to architectural and plastic forms in poetic images in an article on monuments of ancient Greece (1943-1946). Dem-

1. Gabrichevsky A. An introduction to the monograph "Memorial Architecture". P.303 // Memory and Time. From the art archive of the Great Patriotic War of 1941-1945. Responsible editor and compiler T.Malinina. Moscow: Galart. 2011. onstrating the connection of the classic example with the heroic and civic ideals of the ancient Hellenes, the author uses epitaphs (epigrams) in translations of V.Zhukovsky.

"Dead Frasibulus was carried on a shield to his native Pitana / He got seven wounds from the Argive swords / All the wounds were on his chest And Tinnik, an old man, put on the fire / the corpse of the bloodied son and said: / Let the faint-hearted cry, I bury you without tears / My son. Not only mine - you are Lacedaemon's son." (Dioscorides' epigram about the Spartans).

"In a battle, the courage, Proarch, killed you and with this death, / You left your father Phidias' home in a state of sorrow / But a stone sings this beautiful song above you / Singing that you died for your homeland." Anita's epigram².

The pronounced heroic and patriotic content of a poetic image reminds of being the primary source of the Russian classical tradition, which should be followed when creating works of odic sounding, close to such types of memorial structures as a monument and an architectural and sculptural ensemble.

Artistic, creative work becomes sensitive to these impulses. The stylistics of permanent monumental gravestones is based on the traditions of a Russian military headstone. Some authors are inspired by the primary source - the traditions of Russian classicism, while others base on the neoclassical stylizations of the beginning of the last century. National motifs are also processed in the spirit of the national romantic trend developed in line with modernity. Of the multidirectional searches, a peculiar "resultant" vector is designated - the central stylistic tendency that succeeds and develops the principles of modernism of the academic sense (monumental constructive classics). The conciseness of forms, the order principle of composition, strict graphics, and regular arrangement of reliefs, ornament, inscriptions, decorative accent, built on a combination of polished stone and non-ferrous metal, testifies to the closeness of this style to the academic version of Art Deco, giving the tombstone a strict monumentality, emphasizing the heroic principle ${ }^{3}$. Attempts

2. Blavatsky V. "Memorial Architecture of Ancient Greece". P.311, 312. A manuscript of the collective monograph "Memorial Architecture of 1943-1946" // Memory and Time. From the art archive of the Great Patriotic War of 1941-1945. Responsible editor and compiler T.Malinina. Moscow: Galart, 2011.

3. Typical projects of monuments of mass and individual graves of soldiers of the Soviet Army, Navy and partisans who died in battles with Nazi invaders during the Great Patriotic War: developed by the Scientific Research Institute of Public and 


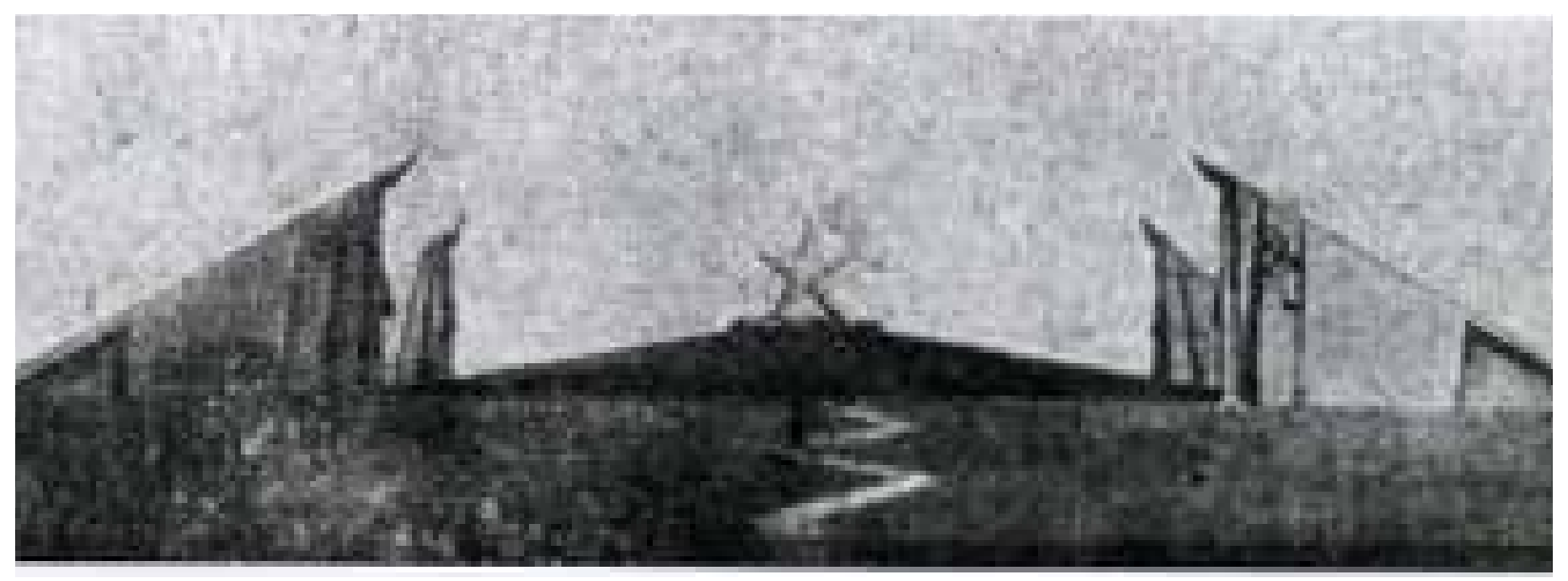

The memorial ensemble at the place of the collective burial. 1943. General view. The whereabouts are unknown. Photo from the Magazine USSR Architecture.

to go beyond it to a chamber, more individualized image, were uncommon in nature; however, it is in such projects that the dynamics of profound processes in the art of the war years are captured.

The direction of searches for stable signs of type, the means of artistic expression, is most evidently illustrated in numerous sketches of architect I.Golosov ${ }^{1}$ (May-June, 1943). The series of drawings is a series of peculiar improvisations. The artist tried to identify the entire arsenal of possible designs fully. Fig. 4 (tables). Drawings in which the means of the symbolic language of propaganda art were widely used made up a whole series. In several other sketches, the author sought a plastic form adequate to the literary symbolic image of "The Flame of the Revolution". In these sketches, Golosov anticipated the rethinking of the revolutionary symbol, its transformation into the "Eternal Flame" - a symbol of the immortality of the ones who gave their lives in World War II.

At the same time, Golosov developed a series of sketches where he used the forms of the constructivist architecture of the 1920s. Two sketches (15.V.43) are variants of a columbarium. Semicircular in plan, cut by several rows of niches, a wall is the central element of these two memorial compositions. Although, in this case, Golosov turned to the constructivist method, the influence of the strongest tendency toward shaping forced him to resort to a peculiar classification of the constructivist form. Hence the strict symmetry of the compositions, the tendency to a precise geometry of forms, an exaggerated scale, and, finally, the use of several tradi-

Industrial AA Structures of the USSR / Ed. N.Colly. Moscow, 1947.

1. Collection of GNIM; RGALI, fond 1979, file 1, d.91. tional elements of memorial architecture (an arch, a column, a pylon, etc.).

In the third, the most numerous series of his drawings, Golosov based his searches on ancient Russian architecture traditions. Most often, in Golosov sketches, there are different variants of a vertically standing tombstone made of brick and in the shape of a battlement tooth. In one variant, the same memorial plate becomes one of a series of identical elements with which a tombstone is compiled for a mass grave. Elements of medieval serfdom architecture, which, as symbols of the people's heroic past, were included in many war years projects, did not actually find application in postwar practice. The projects, in which Golosov turned to the traditions of neoclassicism, played a fundamental role in forming a tombstone associated with the events of the Second World War, its appearance, and its image.

Having grouped the drawings marked with dates, one can notice that the author gradually "cleared" the form of the traditional attributes of the classic tombstone: volutes, torches, palm and oak branches, developing and introducing modern emblems. Torches are replaced by softly falling mourning ribbons (sketches 21.V. 43). A tombstone, decorated with a volute, is replaced by a smooth stone slab of a strict geometric shape with a star depicted on it. A star, graphically drawn, high-relief or deeply embedded in the stone's body, becomes increasingly independent and occupies a more important place in the monument (sketches 24.V.43; 25.V.43; 27.VI.43).

The classic interpretation of form and composition was the fundamental principle of shaping in the drawings of the last series. However, the author excludes the elements that cause direct associations with the symbols of classicism. Gradually, in the process of searching, Golosov came to a strict 


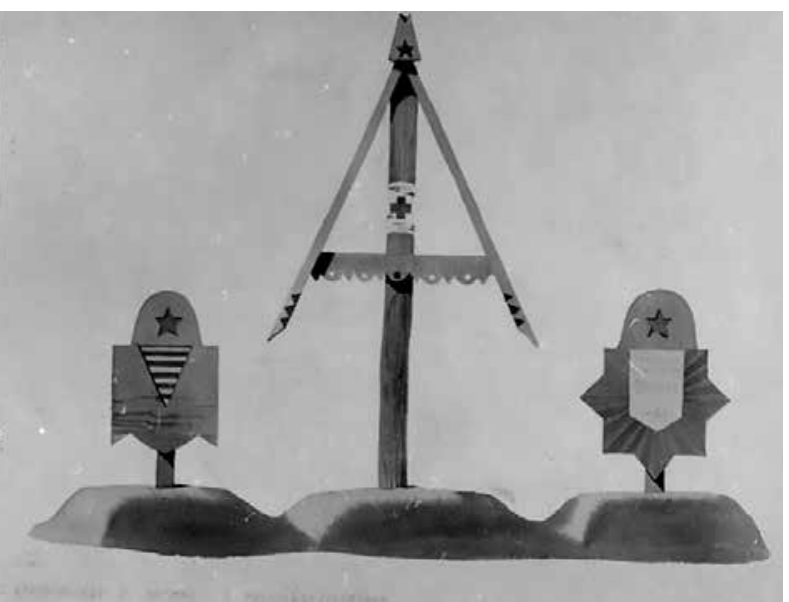

M.Olenev. 1943-1944

lapidary form and a heroic image. Such monuments were widely used in projects and practice of the first post-war years, marked by a cold, academic performance manner. Fig. 5 (a table).

In the epitaph for Anacreon, Antipater of Sidon denoted in one line the main motif of memorial architecture actively involved in the disclosure of the theme of Immortality: "A white tombstone is breathing sweetly with ivy" ${ }^{1}$. This forever green plant symbolized the strength of life and persistence. Being one of the attributes of Dionysus, ivy was associated with his mystery cult, in the ecstatic dances of which, a man, in the words of F.Zelinsky, "was convinced of the originality of his soul, of the possibility for it to live independently of the body and, therefore, of its immortality". In Christian iconography, ivy became a symbol of resurrection and eternal life.

From Alexander Pushkin ("When I wander outside the city thinking...") to Arseny Tarkovsky ("Ivan's Willow", 1958) an image of a tree - this stable mythological and cultural symbol of life embodying the symbolism of eternity as a sign of being, continues to exist in our culture, in our consciousness.

Widely known to this day, Tvardovsky's highly regarded poem "I was killed near Rzhev", which was published immediately after the war and which was born, as the author admitted, with a special feeling and state of mind, is marked by a deep relationship with Ivan Bunin's philosophical and poetic world of poetry, images of nature, imbued with a cosmic worldview, in his works. Bunin's cosmism, which took shape in the spiritual atmosphere of the era of the crisis of Eurocentrism and the general movement

1. Blavatsky V. "Memorial Architecture of Ancient Greece". P.313. A manuscript of the collective monograph "Memorial Architecture of 1943-1946" // Memory and Time. From the art archive of the Great Patriotic War of 1941-1945. Responsible editor and compiler T.Malinina. Moscow: Galart, 2011.

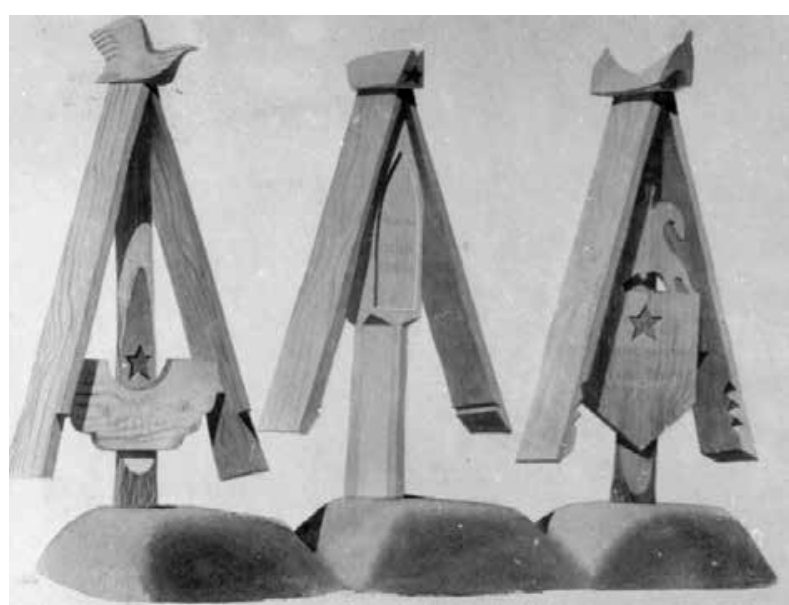

M.Olenev. 1943-1944

of Western culture to the East, has its understanding of man's place in the universe as a small part of the vast and eternal universe ("There is no separate nature from us: <...> every air movement is a movement of our own life"...2). "The eternal commitment of the living, the impossibility of oblivion, an inescapable feeling of oneself in them, and of them in oneself", the expression of which Tvardovsky sought, awakened the images of the poetry of the "Silver Age" in his mind, the images of Bunin's reflection thanks to which the poet's imagination gains freedom. With these allusions, the lyrical monologue of the deceased and the metaphor of the life of the soul were born, regardless of the body, its dissolution in nature, and, therefore, its immortality.

While working on projects for memorial ensembles, architects paid particular attention to the artistic understanding of the role of nature. Its unmatched image attached the quality of uniqueness to a monument. The inexhaustible possibilities of plastic expressiveness made it possible to use it in the architectural composition of an ensemble. Finally, an artist associated the idea of eternity with nature. Thus, architect A.Barutchev (LO SSA), explaining the project of the ensemble of the Theological Cemetery, remarked: "We wanted nature to participate in the composition itself. The plan was based on the idea of 'life in the name of life'. We crowned the mound with a green cap of trees - a young green cemetery. And we wanted it to be like life itself: in the summer - one, in the spring another, in the winter under a hat of snow - the third..."

Solemn representative ensembles in projects for the restoration of cities, which were conceived as monuments of victory (not so much in war but over the war),

2. Slivitskaya O.V. "Cosmic World-view of Ivan Bunin" // Works of the united center of the problems of space thinking, 2009, vol. 2. P.217. 
became immortality symbols. They included monuments, triumphal arches, public buildings of a memorial character (museums, panoramas, pantheons), memorial zones (squares and alleys of heroes), mon- uments-realities, Victory parks. Monuments-bridges, monuments-lighthouses were endowed with features of memorials.

\section{REFERENCES}

1. Alexandrov, P.A., Khan-Magomedov, S.O. 1971. Ivan Leonidov. Moscow: Stroyizdat. p. 101. (in Russian)

2. Vaneyan, S. 2014. "Proizvedeniye iskusstva - ot monumenta k mnemotopu" ["A Work of Art - from a Monument to a Mnemotope"], Proizvedeniye iskusstva kak dokument epokhi [A Work of Art as a Document of the Era], Moscow, vol. 1, p.33 (in Russian)

3. Blavatsky, V. 2011. "Memorial'naya arkhitektura Drevney Gretsii». Rukopis' kollektivnoy monografii «Memorial'naya arkhitektura 1943-1946 gg.» ["Memorial Architecture of Ancient Greece". A manuscript of the collective monograph "Memorial architecture of 1943-1946"], Pamyat' i vremya. Iz khudozhestvennogo arkhiva Velikoy Otechestvennoy voyny 1941-1945 gg. [Memory and Time. From the art archive of the Great Patriotic War of 1941-1945], Moscow, pp. 311-312 (in Russian)

4. Blavatsky, V. 2011. «Memorial'naya arkhitektura Drevney Gretsii». Rukopis' kollektivnoy monografii «Memorial'naya arkhitektura 1943-1946 gg.» ["Memorial Architecture of Ancient Greece". A manuscript of the collective monograph "Memorial architecture of 1943-1946"], Pamyat' i vremya. Iz khudozhestvennogo arkhiva Velikoy Otechestvennoy voyny 1941-1945 gg. [Memory and Time. From the art archive of the Great Patriotic War of 1941-1945], Moscow, p.313 (in Russian)

5. Collection of A.V. Shusev State Museum of Architecture; RGALI, fond 1979, file 1, d.91. (in Russian)

6. Iz stenogrammy vystupleniya A.K. Barutcheva na soveshchaniya Soyuza Arkhitektorov SSSR i Soyuza Khudozhnikov SSSR po voprosam memorial'noy arkhitektury. 3-5 iyunya 1946 g. Rossiyskiy gosudarstvennyy arkhiv literatury $i$ iskusstva [From the transcript of the meeting of the USSR Union of Architects and Union of Artists on the issues of memorial architecture. June 3-5, 1946. RGALI], fond 674, inv.2, f.185, pp.67-68. (in Russian)

7. Iz stenogrammy vystupleniya A.K. Barutcheva na soveshchaniya SSA SSSR i SKH SSSR po voprosam memorial'noy arkhitektury. 3-5 iyunya 1946 goda Rossiyskiy gosudarstvennyy arkhiv literatury $i$ iskusstva [From the transcript of A.Barutchev at the meeting of the USSR Union of Architects and USSR Union of Artists on the issues of memorial architecture. June 3-5, 1946 RGALI], fond 674, inv.2, f.185, l, pp. 11-12. (in Russian)

8. Gabrichevsky, A. 2011. "Vvedeniye v monografiyu Memorial'naya arkhitektura" ["An introduction to the monograph "Memorial Architecture"], Pamyat' i vremya. Iz khudozhestvennogo arkhiva Velikoy Otechestvennoy voyny 1941-1945 gg. [Memory and Time. From the art archive of the Great Patriotic War of 1941-1945] Moscow, p.303. (in Russian)

9. Gabrilovich, E. 1942. "Bratskaya mogila" ["The Mass Grave"], Krasnaya Zvezda [Red star], May 16. (in Russian)

10. Maksimov, P.N. 2011. "Memorial'naya arkhitektura Rossii. Rukopis' kollektivnoy monografii «Memorial'naya arkhitektura 1943-1946»" ["Memorial Architecture of Russia". A manuscript of the collective monograph "Memorial Architecture of 1943-1946"], Pamyat' i vremya. Iz khudozhestvennogo arkhiva Velikoy Otechestvennoy voyny 1941-1945 gg. [Memory and Time. From the art archive of the Great Patriotic War of 1941-1945], Moscow, pp.371-406 (in Russian)

11. Malinina, T.G., Vyazemtseva, A.G. 2019 «I sacrari dei caduti in Urss nei progetti di architettura durante la Seconda Guerra Mondiale. Significati culturali, associazioni storiche e moderne mitologie1», PER NON DIMENTICARE. Sacrari del Novecento a cura di Maria Grazia D'Amelio Palombi Editori, TOR VERGATA Universita Degli Studi di Roma, pp.157-168. (in Italian)

12. Semenova, S. 2004. Metafizika russkoy literatury [Metaphysics of Russian Literature], Moscow, vol. 2, pp.324342 (in Russian)

13. Slivitskaya, O.V. 2009. "Kosmicheskoye mirooshchushcheniye I.A.Bunina" ["Cosmic Worldview of Ivan Bunin"], Trudy ob"yedinennogo tsentra problem kosmicheskogo myshleniya [Works of the united center of the problems of space thinking], vol. 2, p.217.

14. Smid, Stanislav. 1975. Vam Podekovani a Lasku Vam. Bratislava. (in Slovak)

15. Simonov, K. 1943. "Na staroy smolenskoy doroge" ["On the Old Smolensk Road"], Krasnaya Zvezda [Red star], no. 63, March 17 (in Russian)

16. Tipovyye proyekty pamyatnikov bratskikh i individual'nykh mogil voinov Sovetskoy Armii, Voyenno-Morskogo Flota i partizan, pogibshikh v boyakh s nemetsko-fashistskimi zakhvatchikami $v$ gody Velikoy Otechestvennoy voyny: razrabotany NII obshchestvennykh i promyshlennykh sooruzheniy AA SSSR [Typical projects of monuments of mass and individual graves of soldiers of the Soviet Army, Navy and partisans who died in battles with Nazi invaders during the Great Patriotic War: developed by the Scientific Research Institute of Public and Industrial Structures of the USSR AA] Ed.by Colly, N., Moscow, 1947. (in Russian) 
Татьяна Глебовна Малинина

доктор искусствоведения, профессор

главный научный сотрудник

Научно-исследовательского института

Российской академии художеств

e-mail: tgmal01@yandex.ru

Россия, Москва

\title{
ТРАГИЧЕСКИЙ ОПЫТ ПРОЗРЕНИЯ В ХУДОЖЕСТВЕННЫХ МЕМОРАТИВНЫХ ТЕКСТАХ ОТЕЧЕСТВЕННОЙ ПУБЛИЦИСТИКИ, ПОЭЗИИ, ИЗОБРАЗИТЕЛЬНОГО ИСКУССТВА И АРХИТЕКТУРЫ 1940-Х ГОДОВ
}

\author{
На свете смерти нет. \\ Бессмертны все. Бессмертно все. Не надо \\ Бояться смерти ни в семнадиать лет, \\ Ни в семьдесят. Есть только явь и свет, \\ Ни тьмы, ни смерти нет на этом свете. \\ Мы все уже на берегу морском, \\ И я из тех, кто выбирает сети, \\ Когда идет бессмертье косяком \\ Андрей Тарковский, 1965
}

Аннотация: предлагаемая вниманию читателей статья развивает тезисно изложенные положения доклада автора на конференции НИИ теории и истории изобразительных искусств PAX «Тема смерти и бессмертия в изобразительном искусстве Нового и Новейшего времени» (21-22 ноября 2019 г.). Свое обращение к одной из глобальных и вечных тем мирового искусства, связанных с самой сутью бытия человечества и каждого отдельного человека, инициаторы конференции объяснили тем, что если гуманитарные аспекты танатологии давно системно изучаются этнологами и культурологами, то имеющийся обширный искусствоведческий материал еще предстоит собрать воедино.

Из приоритетных направлений, предложенных составителями программы конференции, выбранное автором звучит так: «Смерти нет!»: тема бессмертия, воскресения, вечной и повторяющейся жизни в искусстве». Предметом исследования в публикуемой статье становится тема памяти, занявшая важное место в искусстве периода Великой Отечественной войны. С наибольшей полнотой она выражена в такой сфере творческой и научной мысли военных лет, как мемориальная архитектура. Широко проводившиеся конкурсы на проекты памятников стали заметным явлением художественной жизни тех лет, а сами графические работы вошли в ценный фонд отечественного культурного наследия. Наблюдая рождение нового памятника, автор статьи отмечает, что содержание понятий памяти и памятования в годы войны претерпевает значительные изменения. Отношение к памяти становится сущностным измерением самого понятия мемориальности, ее мировоззренческого, семантического и символического наполнения. Целью этого небольшого исследования становится определение путей взаимодействия воспринимающего, переживающего и интерпретирующего сознания, в процессе которого начинает реализовываться мифологема «возвращения», происходит своеобразная регенерация поврежденных культурных тканей. Обращение к архетипическим понятиям Жизнь, Смерть, Бессмертие, к этим главным сюжетам в произведениях литературы, изобразительного искусства, архитектуры военного времени позволяет увидеть, какие значительные качественные изменения произошли в духовном мире личности и повлекли за собой глубокие перемены в художественном и культурном процессе в целом. 
Ключевые слова: искусство периода Великой Отечественной войны, проектирование и возведение первых военных памятников, творческая и научная мысль военных лет, отраженная в теме памяти, воз-

Мемориальная тема пронизывает все искусство военных лет. Изменения, происходившие в сознании людей, можно увидеть, обратившись к главным человеческим и культурным сюжетам в литературе и искусстве военного времени - Жизни, Смерти, Бессмертия. Они являются основополагающими категориями в системе координат умозрительной философской модели устройства мира (бытия), т.е. «присутствия мира» (в феноменологическом смысле), и модели «присутствия в мире», то есть места человека в нем, его экзистенциального опыта. Обратившись к этим главным человеческим и культурным сюжетам в литературе, изобразительном искусстве и архитектуре военного времени, можно видеть, какие значительные качественные изменения происходят в духовном мире личности. В этот трагический момент сила человеческого духа вызывала к жизни глубинные бытийные смыслы, по сути вневременные.

Нравственной опорой человека становится пробуждение исторической памяти. Мемориальная тема находит отражение и в публицистике, и в поэзии, и в поисках форм увековечения в архитектуре. Многовековая традиция искусства накопила немалый запас художественных средств, создала устойчивую систему типов мемориальных сооружений. Однако всякий раз определенные жизненные ситуации и события вносили свои коррективы, порождая новые варианты тех или иных типов. После революции 1917 года, как известно, идеологическое и материалистическое обоснование роли памяти в общественно-политической жизни и значения памятования в этой парадигме укладывается в простую схему. Такие понятия как Вечность, Слава, Бессмертие, связываются исключительно с заслугами героя перед революцией и его абсолютной обезличенностью перед вечностью как солдата этой революции. Если семантика и символика революционного памятного знака более или менее внятно выражали сложившиеся представления о мемориальности, то язык самих мемориальных форм был беден, однозначен и механистичен.

В военном памятнике периода Великой Отечественной войны, начиная с простого знака на вращение к общечеловеческим ценностям, духовное восхождение с вновь пережитым, адаптированным к глубинным представлениям о мире, природе и месте человека в нем.

месте индивидуального захоронения, меняется всё. В ситуации Второй мировой войны, которая угрожала полным истреблением населения страны, необходима была консолидация всех сил. Провозглашение этой войны отечественной свидетельствовало о готовности господствующей идеологии к компромиссу с другими слоями общества и в первую очередь с крестьянством, более консервативным его слоем, в котором, тем не менее, сохранялась и сберегалась основа единства народа - этого важного ресурса желанной победы. Подчеркивание классовой социальной стратификации общества смягчается компромиссным понятием народ. Важной была и по сути своей христианская мотивация индивида его готовности к жертве. Ощущая себя защитником общего, с чем скреплен в бытии, из чего произошел, что длит в потомстве - его земли, его народа, человек готов пожертвовать жизнью за сохранение этого общего. Сознание ответственности за собственный выбор поднимает его переживания на экзистенциальный уровень.

Философская и художественная мысль пытается припомнить, угадать, уловить черты, отвергнутые, забытые в облике, поведении, речи, характере людей, реанимируя понятие «народ», стремясь воссоздать некую обновленную целостность нации. Отсюда сближение «высокого» и «низкого», фольклорного, профессионального, обладающего чертами примитива и просто самодеятельного в искусстве, отсюда переакцентировки в выборе источников вдохновения, смысловых, символических и образных структурах художественных произведений. Инспирированные (вдохновленные) интеллектуальными усилиями и глубокими переживаниями, чувством сопричастности народной судьбе в художественном творчестве созревают ответы на главные вопросы: «во имя чьё» отдается жизнь и «что там, по ту сторону жизни».

Монументальное искусство, в чью сферу входит мемориальная архитектура, как в зеркале, отражало культурные процессы своего времени. Различные импульсы многоголосого опыта миропонимания, напряженного духовного поиска, религиозной рефлексии, воспринимаемые художественной мыслью, оказываются сфоку- 
сированными в работе над памятником. «Если выбирать из всех именований единого процессуального целого такие определения, как памятник и монумент, - замечает С.С. Ванеян, - то мы можем оказаться лицом к лицу с весьма примечательными и почти что сущностными измерениями художественности и визуальности». В образе монумента и памятника философ видит выражение сложно переплетающихся рефлексивных импульсов «воспринимающего, переживающего и интерпретирующего сознания, за которым, при желании, можно видеть важные онтологические или экзистенциальные горизонты человеческой и бытийности, и событийности» 1 . И действительно, именно здесь ищут ответа на фундаментальные, вечные вопросы человеческого бытия: о Боге, человеке и мире, истории и эсхатологии, о смерти и бессмертии. То, что происходило в миропонимании, мирочувствовании людей и отражалось в искусстве военных лет, по сути своей было возвращением к общечеловеческим ценностям, глубинным, «хтоническим» (почвенным) представлениям о мире, природе и месте человека в нем и духовным восхождением с вновь пережитым, адаптированным к новой реальности. Обращение к архетипам, к самой субстанции Бытия можно назвать онтологической памятью.

Актуальные «задачи дня» и «вечные» проблемы непосредственно связываются в гражданственных, нравственных, социально-философских размышлениях творческих личностей. «Готовились в пророки /Товарищи мои», - позднее скажет Б. Слуцкий.

Следствием было единодушное обращение к корням отечественной культуры. Начинает реализовываться мифологема «возвращения». Происходит это одновременно на разных уровнях «интерпретирующего сознания»: снизу - народной стихии и сверху - культурной памяти. Понимание истории не как давно ушедшего прошлого, а как звена непрерывного процесса бытия, опыта многих поколений, свойственное народному мироощущению, питало и образы искусства. О новых ценностных ориентирах говорит, в частности, интерес архитекторов к «фольклорным» мемориальным формам. В основе этого интереса лежали живые впечатления от увиденного на

1. Ванеян С. Произведение искусства - от монумента к мнемотопу // Произведение искусства как документ эпохи: Сб. статей / Под ред. Т.Г. Малининой. Ч. 1. М.: БуксМАрт, 2014. С. 33. фронте и замеченного в повседневной жизни. Невероятное количество индивидуальных захоронений, отмеченных самодельными памятными знаками, встречались тогда на огромной территории: всюду, где проходили бои. Изготовленные из подручного материала, они стали неотъемлемой частью военного пейзажа и военной жизни. Бывшие фронтовики в своих стихах часто вспоминают именно эти памятники, которые дороги своей подлинностью, сопричастностью обожженной памяти. Звезда памятника возникает в воображении поэта С. Орлова, пронзая синий сумрак угасающего дня: «На закате окончился танковый бой/ Грохотали моторы/ Вдали догорали «пантеры»/ Прокатилась /по синему небу / Над черной землей / и упала / на столбик сосновый/ звезда из фанеры/ («После боя», 1946). В цитируемом уже стихотворении «Памяти поэта Михаила Кульчицкого» (1952) у Слуцкого тоже возникает этот образ: «И мрамор лейтенантов - Фанерный монумент - Венчанье тех талантов, Развязка тех легенд».

Уже в самом начале войны описание фронтовых памятных знаков можно встретить в очерках военкоров: «Древний лесистый озерный край. Холмы, речки, лощины, снова холмы. Один из холмов называется «лысой высотой». Он гол сверху, густо порос снизу кустарником - действительно, лысая голова. На вершине развороченного холма за белым березовым заборчиком, среди четырех недавно посаженных молодых елок высится красный шестигранный обелиск... Справа, упираясь колесами в весеннюю рыжую землю, стоит полуразбитый станковый пулемет... Спускаемся с холма, минуем лес, но и далеко за лесом в теплом мареве весеннего дня виден на лысом холме красный высокий шестигранник - символ красноармейской доблести, вечной русской славы, бессмертной воинской чести» 2. Журналист легко прочитывает смысловые составляющие малого надгробия: революционную символику цвета, воинские эмблемы и классицистическую мемориальную форму пирамиды, символизирующую героическое начало. Чудом сохранившиеся кое-где в городах, на окраинах деревень, у дорог, такие памятники обрели особый художественный смысл. Несмотря на все несовершенство, они всегда - узнаваемые документы эпохи, воздействующие своей подлинностью го-

2. Габрилович Е. Братская могила // Красная звезда. 1942. 16 мая 
раздо сильнее, чем иные велеречивые мемориалы, созданные спустя десятилетия. Памятный знак и его окружение воспринимаются как единый образ - образ времени. Не случайно поэтому в изданном в Южной Чехии альбоме под названием «VAM PODEKOVANI A LASKU VAM» 1 («Вам благодарность и любовь вам») мы видим, что рядом с более поздними, постоянными надгробиями наших солдат в начале 1970-х годов сохранены первоначально поставленные временные памятные знаки...

Под влиянием таких импровизированных надгробий в виде березового столбика с вырезанной на нем звездой, соснового колышка с фанерным листом, сбитого из досок и покрашенного деревянного обелиска, возникает мысль о создании временных деревянных памятных знаков на местах погребений. Её озвучивают армейцы, а архитекторы берутся реализовать. Естественно, что источником вдохновения для пластической интерпретации малых мемориальных форм: на местах единичных захоронений и на небольших братских могилах, - стало деревянное русское надгробие. Именно этот мотив становится важным в поэтическом толковании (перетолковывании) смыслов, которые вкладывает в понятие Родина военкор, писатель, политический деятель К. Симонов в стихотворениях «Родина» (1941), «Ты помнишь, Алеша, дороги Смоленщины?!» (1941), в очерке «На старой смоленской дороге» 2 (1943). Проникновенно личностную лирику автор превращает в гражданственную. Чувство Родины питают близкая сердцу природа («клочок земли, припавший к трем березам», «та горсть земли, которая годится, чтоб видеть в ней приметы всей земли»). Осторожно, как бы размышляя, поэт обращается к А. Суркову со словами: «Ты знаешь, наверное, все-таки Родина». Далее автор признается, что совсем другими глазами видит привычный пейзаж сельской местности средней полосы России и именно этими впечатлениями особо дорожит, что эти маленькие деревеньки на Смоленщине с потемневшими от непогоды старыми крестами погостов и есть самое ценное достояние, ради которого человек может отдать жизнь: «Чувствуешь, какая это наша земля, как невозможно отдать ее, как невозможно вырвать из себя сердце и захотеть после этого все-таки жить». Удивитель-

1. Stanislav Smid Vam podekovani a lasku vam. Bratislava, 1975

2. Симонов К. На старой смоленской дороге // Красная Звезда. № 63. 17 марта 1943 года. ным образом с такой легкостью соединяются в сознании носителя господствующей идеологии еще недавно казавшиеся несовместимыми и даже враждебными представления, обнаруживая тем самым неестественное положение вещей. Так в поэтической форме перед лицом общей опасности манифестируется идея консолидации. Еще одна, далеко не всеми принимаемая, идеологическая составляющая этого единства проявлена здесь в мысли о прощении и примирении, звучащая в строках: «Как будто за каждою русской околицей,/ Крестом своих рук ограждая живых,/ Всем миром сойдясь, наши прадеды молятся/За в бога не верящих внуков своих».

Активная разработка малых мемориальных форм в союзе архитекторов, Военпроекте, мастерских Академии архитектуры побудила известного историка отечественной архитектуры П.Н. Максимова тогда же обратиться к русскому деревянному надгробию. В статье «Мемориальная архитектура России» (1943-1945 гг.) исследователь описал разные типы деревянных надгробий и показал зависимость их формы, силуэта, высоты и декора от природного окружения 3. Разноцветная деревянная колонка с бусиной, завершающаяся объемом кубической формы с портретом (или памятной надписью), над ним - двускатное покрытие, подобное покрытию старых деревянных надгробий, завершаемое звездой. Так выглядит временный памятный знак в одном из набросков Ильи Голосова, который напоминает памятники-столбики с резьбой, окрашенные в разные цвета на лесных кладбищах в Кеми, именно тех, которые описывал Максимов.

Архитектору М. Оленеву удалось удовлетворить два трудно совместимых требования для типового надгробия - с одной стороны, создать устойчивые признаки «типа», с другой - максимально расширить возможности конкретизации содержания типового надгробия. Оленев разработал целую систему символических форм, стилизуя изобразительные атрибуты воинской славы, эмблемы родов войск, боевые награды, знаки различия, виды вооружения, армейские аксессуары. Делал он это как подлинный художник, обобщая и выявляя в первую очередь пластические каче-

3. Максимов П.Н. Мемориальная архитектура России. С. 371406. Рукопись коллективной монографии «Мемориальная архитектура 1943-1946» // Память и время. Из художественного архива Великой Отечественной войнь 1941-1945 гг. / Ответственный редактор и составитель Малинина Т.Г. М.: Галарт, 2011. 
ства формы. Для содержания самого надгробия эта конкретизация была возможностью максимально приблизиться к индивиду, дать о нем самую полную информацию. Главные достоинства памятников оленевского альбома 1943 г. - в единстве конструктивного и декоративного начал, в сохранении основных элементов традиционного надгробия, принципов его композиции, в простоте и выразительности деталей, по характеру и трактовке близких народной деревянной резьбе, в широком использовании полихромии. Оленев - мастер лирического образа. В памятниках его живет наивная непосредственность, незамутненно-идеальное, первоначальное чувство, что так нас пленяет в произведениях народного искусства.

Архитекторы пытались выверять найденные решения, сравнивая их с образцами. Вот что рассказал ректор МАрхИ Андрей Чалдымов (Военпроект) о собственном опыте, выступая на совещании CCA и CCX по вопросам мемориальной архитектуры в июне 1946 года: «...Нечего бояться национальных форм. Я подчеркиваю значение первых попыток создания надгробия национального характера. Обычный столб - символ захоронения одного человека, потом - перекрытие, потом икона или крест. Эта форма вызывается не только соображениями эстетики, но и тектоники. Поэтому, когда в 1943-м пришлось думать о современной форме - форме звезды, очень много понадобилось уделить внимания тому, как этот элемент «устроить», как создать общую композицию памятника, как разместить звезду, ничего не приукрашивая, а дать такую чистую форму. Я сам составил сравнительную таблицу. Если сделать кладь из этих звезд, получится «еж». Представьте себе море остроконечных звезд. Это будет не эстетично, и такая форма не уживется наряду с крестом. Звезду нужно было на что-то поставить. Появляется первая перекладина из простых конструктивных «снарядов», затем наклонная плоская, которая дает образ покоя...» 1.

В эскизах для групповых захоронений и временных памятных знаков для братских захоронений архитекторы широко использовали элементы древнерусского деревянного зодчества, обогащая формы культурными смыслами и художественными ассоциациями.

1. Из стенограммы совещания ССА СССР и СХ СССР по вопросам мемориальной архитектуры. 3-5 июня 1946 г. РГАЛИ, ф. 674, оп. 2, д. 185, л. 67-68.
Круглые деревянные «столбики» часто имели прямое сходство с элементами архитектурного декора XVII века. В более сложных композициях использовались мотивы шатрового покрытия или «сени». Следуя давней традиции возведения маленьких часовен у источников, архитекторы проектировали памятники-родники (Э. Знаменская). Некоторые интерпретировали в дереве форму мемориальной стелы (М. Дзисько и Н. Гайгаров. Военпроект). Выразительными акцентами памятной стелы у Дзисько явились насквозь прорезающие бревенчатую стену сруба узкие вертикальные отверстия-бойницы. В проекте Гайгарова мемориальная стела, сложенная из вертикально стоящих обугленных бревен, напоминала о тысячах сожженных дотла деревень. Это были уникальные произведения архитектурной графики, показанные на выставке «Героический фронт и тыл» (1943), а сегодня хранящиеся в музейных коллекциях.

У военкора «Красной звезды» писателя Андрея Платонова мотив умирания и смерти всепроникающ. Но самое удивительное, что рассказы о войне, об убийствах и смертях у писателя становятся рассказами не просто о жизни, а о жизни бессмертной и вечной. «Вперед, ребята, смерти нет! - звучит призыв к бою в рассказе «Смерти нет!» (1943). Это не фигура речи, а то, что укоренено в сознании, подспудно живет и обнаруживает себя в моменты наивысшего душевного подъема, такой силы высокого жертвенного порыва, который способен победить смерть и запечатлен в христианском «смертию смерть поправ».

«Народный интеллигент, рабочий философ», как называют Платонова отечественные исследователи-филологи, в экстремальной ситуации не только отваживается снова поднимать проклятые вопросы человеческого бытия, но и дает ответы - решительные и последовательные, выраженные страстно и поэтически захватывающе. 2 Транслирует он их через (философствующих Платонов Каратаевых) - духовных героев его военных рассказов. В годы войны идеи автора, близкие ноосферному видению, выражены в мире чувствующих и размышляющих его персонажей, их поразительном «упорстве в бытии». Так будничным, но необычным предстает в газетном очерке «Присяга» А. Платонова ритуал поминовения. Автор неторопливо повествует как о событии повседневной фронтовой жизни (её суровых буден)

2. Семенова Светлана. Метафизика русской литературы. Т. 2. М.: «ПоРог», 2004. С. 324-342. 
- посещении бойцами могилы павших товарищей. И атмосфера, в которой совершается это тихое прощание перед новым боем, и с трудом произносимые непривычные слова ротного с фамилией героя романа «Чевенгур», которые как будто всплывают из глубин памяти. Все это совсем не похоже на ставшую вдруг неуместной громогласную риторику «национально обесцвеченных» революционных ритуалов. «Старинные» слова, речевые формы и обороты наполняют речь командира новыми смыслами, аллюзиями и коннотациями, расцвечивают её новыми красками. В словах Чепурного «сюда, в землю, навечно легли наши люди», «ради того, чтобы отвести смерть от нашего народа» прочувствована «родотворная, жизнехранительная и жизнеспасительная» крестьянская основа народа. В словах командира «они узнали гибель за нашу Родину» выражено пробуждение национального самосознания, объясняемое остротой исторического момента, когда личное и общественное объединяются для борьбы с общим врагом, а само пространство смыслов, вкладываемых в понятие Родина, превращают ее в территорию большого компромисса (национального самосознания, религиозного сознания, революционного сознания).

В особом комментарии нуждаются слова «святые» и «душа»-ключевые понятия русской языковой картины мира. В православии понятие святость появляется с XI в. В новое время, когда культурные парадигмы видоизменяются, первичные смыслы вытесняются при доминировании светской или атеистической идеологии, а слова остаются и значение их трактуется в расширительном (переносном) смысле. В данном же тексте, рожденном наивно-языковыми представлениями, значение слова определенно смещается, приобретая сакральный оттенок.

В очерке Платонова «Труженик войны» (март 1943) в центре внимания автора и его героя оказывается понятие «душа». Иван Толокно смотрел на надвигающийся танк, «и жалость к себе в первый раз тронула его сердце». Он работал всю жизнь, он уставал, он терпел... А теперь в него стреляют, хотят убить, «чтобы сама память об Иване исчезла в вечном забвении, словно человек и не жил на свете. «Врешь! Не возьмешь! - подумал Толокно в минуту наступившей погибели. - А мне Смерть, так Душа останется. Должна бы остаться. Наверное, Родина и есть душа». Душа - вместилище скрытых мыслей и чувств челове- ка. В лексиконе господствующей идеологии этого понятия просто не существует. Так в содержании слова Родина - такой огромности, включающей в себя целый мир воспоминаний, переживаний и мыслей человека, его упований - отодвигается и сужается доля идеологической составляющей.

Фразеологизмы из речи командира «они пережили высшую судьбу воина и выполнили свой долг, не щадя крови и самой жизни» и «стали святыми людьми в вечной памяти нашего Отечества» восходят к воинской риторике, к героике Отечественной войны 1812 г. Теме воинской доблести и славы в архитектуре русского классицизма уделяет внимание и П.Н. Максимов в уже упоминавшейся статье, следуя общей тенденции обращения к отечественной традиции.

Общую картину духовного климата эпохи дополняет анализ исторического опыта искусства припоминания и интерпретации культурной традиции, соотнесение его с современностью, продемонстрированный отечественными учеными: историками архитектуры, искусствоведами и археологами, которые приняли участие в работе над коллективным трудом, посвященным мемориальной теме в архитектуре. Название коллективной монографии «Мемориальная архитектура» (1943-1946) было не совсем привычным для слуха. А.Г. Габричевский, составитель, редактор, в вводной статье дает пояснения: «Рёскин в свое время писал об архитектуре: «Мы можем жить без нее и почить без нее, но вспоминать без нее мы не можем», и продолжает мысль, утверждая, что архитектура всегда в известной мере мемориальна, и, прежде всего, как памятник человеческого труда и человеческого искусства. Это ее качество находит себе выражение в системе художественных признаков, которую мы называем монументальностью». 1 Главная особенность концепции Габричевского - расширение границ исследования, выход за пределы мемориальной архитектурной типологии в широкое пространство культурной памяти. Другой автор этого коллективного труда В. Блаватский в статье о памятниках античной Греции (1943-1946) открывает ценности античной культуры, в поэтических образах расшифровывая пластические аналоги

1. Габричевский А. Введение к монографии «Мемориальная архитектура» // Память и время. Из художественного архива Великой Отечественной войны 1941-1945 гг. / Ответственный редактор и составитель Малинина Т.Г. М.: Галарт. 2011. С. 303. 
или находя аналоги архитектурным и пластическим формам в поэтических образах. Демонстрируя связь классического образца с героическими и гражданственными идеалами древних эллинов, автор привлекает эпитафии (эпиграммы) в переводах В.А. Жуковского.

«Мертвым внесли на щите Фрасибула в родную Питану / Семь от аргивских мечей ран получил он в бою/ Все на груди были раны И труп окровавленный сына / Тинник старик на костер сам положил и сказал:/ Пусть малодушные плачут, тебя же без слез хороню я / Сын мой. Не только ведь мой - Лакедемона ты сын» (Эпиграмма Диоскурида о спартанцах).

«В битве отвага, Проарх, тебя погубила и смертью/ Дом ты отца своего Фидия в горе поверг,/ Но над тобой поет эту песню прекрасную камень/ Песню о том, что погиб ты за отчизну свою. Эпиграмма Аниты. 1

Ярко выраженное героико-патриотическое содержание поэтического образа напоминает о себе как о первоисточнике отечественной классической традиции, которой надлежит следовать при создании произведений одического звучания, близких таким типам мемориальных сооружений, как монумент и архитектурно-скульптурный ансамбль.

Художественное творчество становится чутким к этим импульсам. Стилистика постоянных монументальных надгробий базируется на традициях отечественного военного надгробия. Одни авторы черпают из первоисточника - традиции русского классицизма, другие исходят из стилизаций неоклассики начала прошлого века. Национальные мотивы также перерабатываются в духе национально-романтического направления, сложившегося в русле модерна. Из разнонаправленных поисков обозначается своеобразный «результирующий» вектор - основная стилистическая тенденция, которая преемствует и развивает принципы модернизма академического толка (монументальной конструктивной классики). Лаконичность форм, ордерный принцип композиции, жесткая графичность и регулярность расположения рельефов, орнамента, надписей, декоративный акцент, построенный на сочета-

1. Блаватский В. Мемориальная архитектура античной Греции Рукопись коллективной монографии «Мемориальная архитектура 1943-1946» // Память и время. Из художественного архива Великой Отечественной войны 1941-1945 гг. / Ответственный редактор и составитель Малинина Т.Г. М.: Галарт, 2011. С. 311, 312. нии полированного камня с цветным металлом, свидетельствуют о близости данной стилистики академической версии ар деко, придающей надгробию строгую монументальность, подчеркивающую героическое начало. 2 Попытки выйти за её пределы к камерному, более индивидуализированному образу носили аномальный характер, но именно в таких проектах улавливается динамика глубинных процессов в искусстве военных лет.

Нагляднее всего направление поисков устойчивых признаков типа, средств художественной выразительности прослеживается в многочисленных эскизах архитектора И.А. Голосова 3 (майиюнь 1943). Цикл рисунков представляет собой ряд своеобразных импровизаций. Автор пытается как можно полнее выявить весь арсенал возможных решений. Целую серию составили рисунки, в которых широко использовались средства символического языка агитмассового искусства. В ряде других эскизов автор ищет пластическую форму, адекватную литературному символическому образу «Пламя Революции». В этих эскизах Голосов предвосхищает переосмысление революционного символа, превращение его в «Вечный огонь» - символ бессмертия павших во Второй мировой войне.

Одновременно Голосов разработал серию эскизов, где использовал формы конструктивистской архитектуры 1920-х годов. Два эскиза (15.V.43) представляют собой варианты колумбария. Центральным элементом этих двух мемориальных композиций является полукруглая в плане стена, прорезанная несколькими рядами ниш. Хотя Голосов и обращается в данном случае к конструктивистскому методу, влияние наиболее сильной тенденции формообразования заставляет его прибегнуть к своеобразной классицизации конструктивистской формы. Отсюда строгая симметрия композиций, тяготение к четкой геометризации форм, преувеличенному масштабу и, наконец, использование ряда традиционных элементов мемориальной архитектуры (арка, колонна, пилон и др.).

2. Типовые проекты памятников братских и индивидуальных могил воинов Советской Армии, Военно-Морского Флота и партизан, погибших в боях с немецко-фашистскими захватчиками в годы Великой Отечественной войны: разработаны НИИ общественных и промышленных сооружений АА ССС / Под ред. Н.Я. Колли. М.,1947.

3. Собрание ГНИМА; РГАЛИ, ф. 1979, оп.1, д. 91. 
В третьей, самой многочисленной серии рисунков Голосов ведет свои поиски, опираясь на традиции древнерусской архитектуры. Чаще всего в зарисовках Голосова встречаются различные варианты вертикально стоящей надгробной плиты, сложенной из кирпича, имеющей форму зубца крепостной стены. В одном из вариантов та же мемориальная плита становится одним из ряда идентичных элементов, с помощью которых компонуется надгробие для братского захоронения. Элементы средневекового крепостного зодчества, которые, как символы героического прошлого народа, вошли во многие проекты военных лет, в послевоенной практике фактически не нашли применения. Проекты же, в которых И.А. Голосов обратился к традициям неоклассики, сыграли основополагающую роль в формировании надгробия, связанного с событиями Второй мировой войны, его облика и образа.

Сгруппировав отмеченные датами рисунки, можно заметить, что автор постепенно «очищал» форму от традиционных атрибутов классицистического надгробия: волют, факелов, пальмовых и дубовых ветвей, разрабатывая и вводя современную эмблематику. На смену факелам приходят мягко спадающие траурные ленты (эскизы 21.V.43). Надгробие, украшенное волютой, сменяется гладкой каменной плитой строгой геометрической формы с изображенной на ней звездой. Графически прочерченная, горельефная или глубоко врезанная в тело камня звезда приобретает все большую самостоятельность и занимает более значительное место в памятнике (эскизы 24.V.43; 25.V.43; 27.VI.43).

Основополагающим принципом формообразования в рисунках последней серии явилась классицистическая интерпретация формы и композиции. Вместе с тем автор освобождается от элементов, вызывающих прямые ассоциации с символикой классицизма. Постепенно в процессе поисков Голосов приходит к строгой лапидарной форме и героическому образу. Именно такие памятники получили широкое распространение в проектах и практике первых послевоенных лет, отмеченных холодноватой академизированной манерой исполнения.

В эпитафии Анакреонту Антипатр Седонский одной строкой обозначает основной мотив мемориальной архитектуры, активно привлекаемый к участию в раскрытии темы Бессмертия: «И сла- достно плющем белая дышит плита» 1 . Это вечнозеленое растение символизировало силу жизни и стойкость. Будучи одним из атрибутов Диониса, плющ был связан с его мистериальным культом, в экстатических плясках которого человек, по выражению Ф.Ф. Зелинского, «убеждался в самобытности своей души, в возможности для нее жить независимо от тела и, следовательно, в ее бессмертии». В христианской иконографии плющ преемственно становится символом воскресения и вечной жизни.

От Александра Пушкина («Когда за городом, задумчив, я брожу...») до Арсения Тарковского («Иванова ива», 1958) в нашей культуре, в нашем сознании продолжает существовать образ древа - этот устойчивый мифологический и культурный символ жизни, который заключает в себе символику вечности как знак бытия.

Широко известное и по сей день высоко оцениваемое стихотворение Твардовского «Я убит подо Ржевом», опубликованное сразу после войны и рожденное, как признавался автор, особым чувством и состоянием души, отмечено глубоким родством с философски-поэтическим миром поэзии И. Бунина, образами природы, проникнутой космическим миросозерцанием, в его произведениях. Бунинскому космизму, сложившемуся в духовной атмосфере эпохи кризиса европоцентризма и общего движения западной культуры на Восток, свойственно свое понимание места человека в мироздании, как малой части бескрайней и вечной Вселенной («Нет никакой отдельной от нас природы: <...> каждое движение воздуха есть движение нашей собственной жизни...» 2). «Навечное обязательство живых, невозможность забвения, неизбывное чувство как бы себя в них, а их в себе», к выражению которых стремился Твардовский, пробуждают в его сознании образы поэзии «серебряного века», образы бунинской рефлексии, благодаря чему воображение поэта обретает свободу. Именно этими аллюзиями рождены лирический монолог погибшего и метафора жизни души независимо от

1. Блаватский В. Мемориальная архитектура античной Греции. Рукопись коллективной монографии «Мемориальная архитектура 1943-1946» // Память и время. Из художественного архива Великой Отечественной войны 1941-1945 гг. / Ответственный редактор и составитель Малинина Т.Г. М.: Галарт. 2011. С. 313.

2. Цит. по: Сливицкая О.В. Космическое мироощущение И.А. Бунина // Труды объединенного центра проблем космического мышления. 2009. Т. 2. С. 217. 
тела, растворенности ее в природе, а, стало быть, ее бессмертия.

Художественному осмыслению роли природы при работе над проектами мемориальных ансамблей архитекторы уделяли особое внимание. Её неповторимый облик придавал памятнику качество уникальности. Неисчерпаемые возможности пластической выразительности позволяли использовать ее в архитектурной композиции ансамбля. Наконец, с природой художник связывал представления о вечности. Так архитектор А.К. Барутчев (ЛО ССА), давая пояснения к проекту ансамбля Богословского кладбища, замечал: «Нам хотелось, чтобы уже в самой композиции участвовала природа. В основу <замысла> была положена идея «жизнь во имя жизни». Мы увенчали курган зеленой шапкой деревьев - зеленое молодое кладбище. И мы хотели, чтобы оно было как сама жизнь: летом - одно, весной - другое, зимой под шапкой снега - третье...» 1

Символами бессмертия становились торжественные репрезентативные ансамбли в проектах восстановления городов, которые мыслились как памятники Победы (не столько в войне, сколько над войной). Они включали монументы, триумфальные арки, общественные здания мемориального характера (музеи, панорамы, пантеоны), мемориальные зоны (скверы и аллеи героев), памятники-реалии, парки Победы. Чертами монументов наделялись памятники-мосты, памятники-маяки.

1. Из стенограммы выступления А.К. Барутчева на совещании ССА СССР и СХ СССР по вопросам мемориальной архитектуры. 3-5 июня 1946 г. РГАЛИ, ф. 674, оп. 2, д. 185, л. 11-12.

\section{БИБЛИОГРАФИЯ}

1. Ванеян С. Произведение искусства - от монумента к мнемотопу // Произведение искусства как документ эпохи: Сб. статей / Под ред. Т.Г. Малининой. 4.1. - М.: БуксМАрт, 2014. - С. 33.

2. Габрилович Е. Братская могила // Красная звезда. - 1942. - 16 мая.

3. Stanislav Smid. Vam podekovani a lasku vam. Bratislava. - 1975.

4. Симонов К. На старой смоленской дороге // Красная Звезда. - № 63, 17 марта 1943 года.

5. Максимов П.Н. Мемориальная архитектура России. Рукопись коллективной монографии «Мемориальная архитектура 1943-1946» // Память и время. Из художественного архива Великой Отечественной войны 1941-1945 гг. / Ответственный редактор и составитель Малинина Т.Г. М.: Галарт, 2011. - С. 371406.

6. Из стенограммы совещания ССА СССР и СХ СССР по вопросам мемориальной архитектуры. 3-5 июня 1946 г. РГАЛИ, ф. 674, оп. 2, д. 185, л. 67-68.

7. Семенова Светлана. Метафизика русской литературы. - Т. 2. М.: «ПоРог», 2004. - С. 324-342.

8. Габричевский А. Введение к монографии «Мемориальная архитектура» // Память и время. Из художественного архива Великой Отечественной войны 1941-1945 гг. / Ответственный редактор и составитель Малинина Т.Г. - М.: Галарт. 2011. - С. 303.

9. Блаватский В. Мемориальная архитектура античной Греции. Рукопись коллективной монографии «Мемориальная архитектура 1943-1946» // Память и время. Из художественного архива Великой Отечественной войны 1941-1945 гг. / Ответственный редактор и составитель Малинина Т.Г. - М.: Галарт. 2011. - С. 311, 312.

10. Типовые проекты памятников братских и индивидуальных могил воинов Советской Армии, Военно-Морского Флота и партизан, погибших в боях с немецко-фашистскими захватчиками в годы Великой Отечественной войны: разработаны НИИ общественных и промышленных сооружений АА СССР / Под ред. Н.Я. Колли. - М., 1947.

11. Собрание ГНИМА; РГАЛИ, ф. 1979, оп. 1, д. 91.

12. Блаватский В. Мемориальная архитектура античной Греции. Рукопись коллективной монографии «Мемориальная архитектура 1943-1946» // Память и время. Из художественного архива Великой Отечественной войны 1941-1945 гг. Ответственный редактор и составитель Малинина Т.Г. - М.: Галарт, 2011.

13. Сливицкая О.В. Космическое мироощущение И.А Бунина // Труды объединенного центра проблем космического мышления. - 2009. - Т. 2. - С. 217.

14. Из стенограммы выступления А.К. Барутчева на совещании ССА СССР и СХ СССР по вопросам мемориальной архитектуры. 3-5 июня 1946 г. - РГАЛИ, ф. 674, оп. 2, д. 185, л.11-12.

15. Александров П.А., Хан-Магомедов С.О. Иван Леонидов. - М.: Стройиздат. - 1971. - С. 101.

16. Malinina T.G., Vyazemtseva A.G. «I sacrari dei caduti in Urss nei progetti di architettura durante la Seconda Guerra Mondiale. Significati culturali, associazioni storiche e moderne mitologie1».- PER NON DIMENTICARE. Sacrari del Novecento a cura di Maria Grazia D'Amelio Palombi Editori, TOR VERGATA Universita Degli Studi di Roma, 2019. - P. 157-168. 